\title{
Time-Varying Capital Requirements and Disclosure Rules Effects on Capitalization and Lending Decisions
}

\author{
Imbierowicz, Björn; Kragh, Jonas; Rangvid, Jesper
}

Document Version

Accepted author manuscript

Published in:

Journal of Money, Credit and Banking

DOI:

10.1111/jmcb.12506

Publication date:

2018

\section{License}

Unspecified

Citation for published version (APA):

Imbierowicz, B., Kragh, J., \& Rangvid, J. (2018). Time-Varying Capital Requirements and Disclosure Rules:

Effects on Capitalization and Lending Decisions. Journal of Money, Credit and Banking, 50(4), 573-602.

https://doi.org/10.1111/jmcb.12506

Link to publication in CBS Research Portal

\section{General rights}

Copyright and moral rights for the publications made accessible in the public portal are retained by the authors and/or other copyright owners and it is a condition of accessing publications that users recognise and abide by the legal requirements associated with these rights.

Take down policy

If you believe that this document breaches copyright please contact us (research.lib@cbs.dk) providing details, and we will remove access to the work immediately and investigate your claim. 


\title{
Time-Varying Capital Requirements and Disclosure Rules: Effects on Capitalization and Lending Decisions
}

\section{Björn Imbierowicz, Jonas Kragh, and Jesper Rangvid}

\author{
Journal article (Accepted manuscript*)
}

\section{Please cite this article as:}

Imbierowicz, B., Kragh, J., \& Rangvid, J. (2018). Time-Varying Capital Requirements and Disclosure Rules: Effects on Capitalization and Lending Decisions. Journal of Money, Credit and Banking, 50(4), 573-602. https://doi.org/10.11l1/jmcb.12506

This is the peer reviewed version of the article, which has been published in final form at DOI: https://doi.org/10.1111/imcb.12506

This article may be used for non-commercial purposes in accordance with Wiley Terms and Conditions for Self-Archiving

* This version of the article has been accepted for publication and undergone full peer review but has not been through the copyediting, typesetting, pagination and proofreading process, which may lead to differences between this version and the publisher's final version AKA Version of Record. 


\title{
Time-varying capital requirements and disclosure rules: Effects on capitalization and lending decisions
}

\author{
Björn Imbierowicz
}

\author{
Jonas Kragh
}

\author{
Jesper Rangvid *
}

\begin{abstract}
This paper investigates how banks' capital and lending decisions respond to changes in bankspecific capital and disclosure requirements using proprietary regulatory data from the Danish FSA on the full population of banks in Denmark. We find that banks adjust their capital ratio via different channels, depending on the sign of the change in the capital ratio a bank is required to fulfill. An increase in the required capital ratio results in an increase in a bank's capital ratio, brought about via a decrease in asset risk. Given that total lending as well as equity are not affected this indicates a reshuffling of loans towards those with lower risk weights. Additionally, the buffer banks choose to hold over and above the required capital ratio decreases. A decrease in the required capital ratio implies more lending to firms and a higher buffer between actual and required capital but also a decrease in Tier 1 capital and higher bank leverage. These effects are most pronounced in a regime when the required capital ratio is a "hard" requirement, meaning that the supervisor withdraws the banking license when it is breached. In contrast to the intention in Basel III, we do not observe differences between confidential and public disclosure of banks' regulatory capital ratio requirement. Our results empirically illustrate a tradeoff between bank resilience and a fostering of the economy through more bank lending using banks' capital ratio as policy instrument.
\end{abstract}

JEL Classification: G21, G28.

Keywords: capital requirement, bank lending, bank capital structure, capital disclosure rules

\footnotetext{
We thank participants at seminars at Danmarks Nationalbank and the Danish FSA, as well as an anonymous referee for helpful comments. Imbierowicz and Kragh gratefully acknowledge support from the Center for Financial Frictions (FRIC), grant no. DNRF102.

* All authors are with Copenhagen Business School, Department of Finance. Imbierowicz and Kragh are also with the Center for Financial Frictions (FRIC). Send correspondence to Jesper Rangvid, Copenhagen Business School, Solbjerg Plads 3 , 2000 Frederiksberg, Denmark; telephone: +45-3815 3615; E-mail: jr.fi@cbs.dk.
} 


\section{Introduction}

Financial crises are often preceded by periods of strong growth in credit (Schularick \& Taylor, 2012), and followed by periods of severe recessions (Bordo et. al., 2001; Laeven and Valencia, 2012; Reinhart and Rogoff, 2014). Aiming at reducing the likelihood and severity of future financial crises, supervisory authorities around the world have been equipped with new tools to address risks in the banking system. Two important regulatory tools are capital requirements and disclosure rules. The new regulatory regime - Basel III - introduces countercyclical capital requirements and enhanced disclosure requirements. Counter-cyclical capital requirements aim at making banks more resilient during periods of stress in the economy. They mandate higher levels of capital during periods of strong credit growth that banks can then rely upon when the tides turn. In addition, if banks view capital as expensive, higher countercyclical capital requirements might even restrain credit growth during the boom period. Following the same logic, this similarly implies that in periods of recessions, capital requirement decreases might encourage bank lending and thereby dampen recessionary effects. Disclosure requirements aim at providing market participants with a clearer picture of risk taking in banks: If market participants can see risks building up, they can hike funding costs for more risky banks. This should also dampen risk taking.

Despite the importance attached to the new regulatory regime, relatively little systematic evidence exists about the effects of time-varying capital requirements and disclosure rules on bank behavior. This is mainly due to the simple fact that time-varying capital requirements existed in only a few countries prior to Basel III. In this paper, we analyze the effects on banks' lending, capital accumulation, and asset risk decisions resulting from changes in bank-specific time-varying capital requirements. A policy change that tightened disclosure rules by mandating banks to publish their individual capital requirement allows us to additionally study how different 
disclosure rules influence banks' reactions to changes in capital requirements. We use the unique implementation of the Basel II framework since 2007 in Denmark as our setting to identify both the effects from time-varying capital requirements as well as disclosure rules.

In general, the Basel II framework specifies a flat $8 \%$ capital requirement. However, the Danish regulator requires banks to fulfill an additional bank-specific capital requirement on top of this. The interesting features of this bank-specific capital requirement are three-fold. First, it varies over time, i.e. it increases (decreases) when risks in a bank increase (decrease). Second, it is specific to each individual bank, i.e. is based on the characteristics of each individual bank. And third, the regulator ensures that the requirement is calculated according to its standards. Banks do not only face severe charges if they (intentionally or unintentionally) misreport their required capital ratio to the regulator but a misreporting is also publicly announced by the FSA with potentially detrimental reputational effects for the bank. In other words, the time-varying bank-specific capital requirement changes we investigate follow the requirements of the regulator when being calculated. For our identification strategy, it is also important to notice that the individual bank capital requirement has generally been the binding capital requirement: several banks were closed when breaching their individual capital requirement, even when their level of capital still exceeded the $8 \%$ hurdle generally applied in Basel II (Danmarks Nationalbank, 2013).

In addition to this unique implementation of Basel II, our sample period includes two exogenous policy-induced regulatory changes for banks. First, bank-specific time-varying capital requirements were confidential and only known to the FSA (and the individual banks themselves, of course) during the first part of our sample from 2007 until 2009. Thereafter, however, they were publicly disclosed. We use this variation to examine whether banks react differently between private and public disclosure of bank capital requirements. Second, the severity of the 
consequences of breaching the bank-specific capital requirements was changed during our sample period (in 2013). Hence, we are able to compare banks' reactions to changes in capital requirements during a period where the consequences of breaching the capital requirements were severe (banking licenses were withdrawn) to reactions during periods where the consequences of breaching requirements were less severe (banking licenses were not withdrawn but different supervisory actions were taken). The lessons learned from studying the reaction of banks are important from a policy perspective because the counter-cyclical capital buffer in Basel III is a soft requirement, i.e. banks will face supervisory actions but the banking license is not withdrawn if the capital requirement is violated.

We analyze proprietary quarterly bank-level data of the full population of banks in the Danish banking market during the 2007 to 2014 period. We observe 1,652 quarter-to-quarter changes in bank-specific capital requirements, varying between 25 basis points and large changes of up to several percentage points. In all analyses, we employ a simultaneous equations approach to account for the possibility that bank policy decisions might not be orthogonal to each other. The first main question we are after is if and how a bank in general adjusts its capital ratio when the regulatory capital requirement changes. Given that the capital ratio is calculated as equity over risk-weighted assets, there exist three direct channels through which a bank can address a change in the regulatory capital requirement: i. increase equity; ii. decrease assets such as, e.g., loans; and iii. decrease the risk of assets such as, e.g., issue relatively more loans with a lower risk weight. The first part of our analysis focuses on identifying which of these channels banks select.

We observe that a change in the regulatory capital ratio in general induces banks to adjust their lending exposure as well as their asset risk but not their level of equity capital. This is robust to macroeconomic and monetary policy related effects that we capture via time period fixed 
effects and bank fixed effects. ${ }^{1}$ Our data allow us to differentiate between increases and decreases in regulatory capital requirement. We hypothesize that the reactions of banks to an increase in the required capital ratio might be different from the reactions to a decrease, because banks are able to address a decrease much easier.

We find that when the minimum capital ratio required by the regulator increases, banks increase their capital ratio by decreasing the risk of their assets while their total loan volume as well as equity capital are not affected. This indicates that the main effect of an increase in the regulatory capital requirement is a reshuffling of loans towards those with lower risk weight. For a decrease in the regulatory capital requirement, we find that banks increase their lending. In this case, we additionally observe a weakly significant effect on equity which decreases when the regulatory capital requirement decreases.

To better understand the underlying mechanisms of these results, we have a more detailed look at the individual channels of banks' capital ratio adjustment in the second part of our analyses. Besides changing its capital structure, banks can also decide to reduce or increase the buffer of capital they hold over and above the level of required capital. In fact, the banks in our data have a capital buffer of $9.1 \%$-points on average (across banks and time). We therefore add the buffer between a bank's actual capital ratio and the regulatory required minimum to our main dependent variables. We also add the growth in Tier 1 capital as well as bank leverage, defined as a bank's assets over Tier 1 capital, to our analysis. While the former can be regarded as a proxy for equity issuances and to some extent dividend payments, ${ }^{2}$ the latter allows for an analysis of an unweighted capital requirement, which is also included in Basel III to constrain excess leverage and protect against risk model failures. Finally, we also investigate liquid assets to test if changes

\footnotetext{
${ }^{1}$ We include bank and time fixed effects in all our regression specifications.

${ }^{2}$ We do not have data on equity issuances or share repurchases available.
} 
in risk-weighted assets are driven by changes in liquid assets, which have zero risk weight, or if they are related to the risks in the bank's loan portfolio.

Adding all these variables to our simultaneous equations estimation setup shows that banks do not adjust their capital structure one-to-one to the change in regulatory requirement. We find that the buffer between actual and regulatory capital decreases (increases) when the regulatory capital requirement increases (decreases). Accordingly, the capital buffer provides banks with some flexibility when they face changes in capital requirements. Furthermore, the weakly significant negative effect on equity we observe when banks face decreases in regulatory capital requirements, is the result of a reduction in Tier 1 capital. This latter finding is confirmed by an increase in bank leverage. It might be driven by e.g. (an increase of) dividend payments. ${ }^{3}$ We do not observe any change in liquid assets when the capital ratio requirement changes. In sum, an increase in the regulatory capital requirement results in a higher capital ratio due to less asset risk and a lower capital buffer, while a decrease leads to a higher buffer as well as a lower capital ratio due to less Tier 1 capital and an increase in lending. To better understand the latter effect, we also split loans into retail loans, firm loans, and loans to public institutions using annual data. We find that a decrease in the required capital ratio is accompanied by the issuance of more loans to firms. Overall, this reflects a tradeoff for the regulator and policymakers between a more resilient banking system and a fostering of the economy through more bank lending using the capital ratio as a policy instrument. It also implies that raising capital requirements does not restrain banks from issuing new loans. Reducing requirements, on the other hand, enables banks to extend new loans. Even when our setting is different from the countercyclical capital buffer of Basel III, an implication of our results is that increasing requirements does not reduce loan growth, but reducing requirements facilitates loan growth.

\footnotetext{
${ }^{3}$ We conjecture that banks pay (higher) dividends when the regulatory capital requirement decreases but do not have data on bank dividend payments available.
} 
We also verify that the time-varying bank-specific capital requirement changes we investigate follow the requirements of the regulator when being calculated. We do so using data from on-site visits from the FSA. We study those cases where the visited banks receive an injunction from the FSA because the bank has made an incorrect calculation or underestimation of risks. We hypothesize that if banks systematically misreported their regulatory capital requirement, we should observe differences between situations where the FSA inspects a bank on-site and immediately establishes a new regulatory capital ratio and other cases where capital requirements are changed. We observe no differences. ${ }^{4}$ This confirms that banks calculate the requirement following the standards defined by the regulator. Finally, we investigate if systemically important financial institutions (SIFIs), as defined by the Danish FSA, adjust their capital ratio differently. In general, we do not observe any such these effects. Nevertheless, we observe weakly significant positive effects on bank equity of SIFIs for increases in regulatory capital requirement indicating that at least some SIFIs had access to external equity capital markets despite periods of market stress during our observation period.

In the last part of our analysis, we seek to answer if effects are different when banks have to disclose their capital ratio publicly. Furthermore, we investigate if differences exist between a "hard" capital requirement where the banking license is withdrawn when the capital requirement is violated and a "soft" requirement which "only" induces regulatory actions apart from bank closure. Bank-specific time-varying capital requirements were confidential from 2007 until 2009 and had to be publicly disclosed thereafter. In the period 2007 until 2012, the supervisor acted "hard" and withdrew the banking license when the regulatory capital requirement was violated. From 2013 on, however, the supervisor acted "soft" by implementing supervisory actions but did

\footnotetext{
${ }^{4}$ Anecdotal evidence suggests that most of the injunctions are issued because of a diverging appraisal of collateral between the bank and the FSA. Our results reveal that differences in the definition of equity capital seem to be the main reason for an injunction by the FSA.
} 
not close a bank when it breached its required capital ratio. The counter-cyclical capital buffer in Basel III is also a "soft" requirement.

Our results show no differences between private and public disclosure of bank capital ratios. However, we observe that effects are strongest when the regulator acts "hard" and withdraws the banking license when the capital ratio required by the regulator is breached. A "hard" requirement implies the statistically as well as economically largest effects. In contrast, we observe that a "soft" requirement implies that banks do not adjust their capital ratio at all when the regulatory ratio changes but use the flexibility of their capital buffer. This might be important for the implementation and enforcement of the counter-cyclical capital buffer in Basel III, as this is also a "soft" requirement.

The remainder is organized as follows. The next section provides an overview of the literature, the institutional details of the Danish banking market and its regulation, as well as a description of the econometric methodology used in our analyses. Section 3 describes the data and presents summary statistics. Section 4 presents multivariate results on the impact of changes in regulatory capital requirement on bank capital ratio followed by our results on disclosure requirements and "hard" versus "soft" capital requirement. Section 5 concludes.

\section{Background}

This section first summarizes the literature related to our study. Thereafter, it describes the institutional details of the Danish banking market and the relevant regulations and changes of these during the time period we cover in our analysis. Finally, the section presents the econometric methodology used in the remainder of the paper. 


\subsection{LITERATURE}

The benefits and costs of higher capital requirements in banks have been a highly debated topic since the financial crisis of 2007-2009. Do higher capital requirements induce banks to hold more capital and thereby increase banks' resilience, or do banks react to higher capital requirements by reducing excess capital buffers? And do higher capital requirements imply lower lending from banks to households and firms? Advocates of higher equity levels in banks argue that higher capital requirements entail large social benefits in terms of a safer and more resilient financial system. They also argue that these beneficial effects come with only minimal costs to society (see, e.g., Admati et al., 2013). In contrast, the financial industry, which is affected by the tighter regulation, argues that equity financing is expensive and that higher capital requirements will be costly for society because banks will have to reduce lending to the real economy (see also, e.g., Admati et al., 2013).

Bank capital is important because it creates a cushion that banks can use to withstand shocks that create losses on the balance sheet: The more capital a bank holds, the larger is the distance to insolvency and the more time managers have to cope with stressful periods (Thakor, 2014). In addition, more capital may improve banks' incentives to behave prudently because managers and shareholders have more skin in the game when managing the bank.

Banks are subject to regulation, not least because bank failures are associated with externalities (Freixas and Rochet, 2008). Failures can 1) cause bank runs due to the risk that customers face losses on deposits, 2) disrupt the flow of credit to the real economy, and 3) cause financial contagion which might threaten financial stability. A key objective in banking regulation is that banks hold sufficient capital. In general, banks have a capital buffer over and above the minimum capital requirement. The reasons for this can be to weather economic downturns and thereby prevent costly supervisory interventions, ranging from the most severe 
where banking licenses are withdrawn to less severe, such as restriction on dividend policies etc., and/or it can be to reduce financial distress costs (Marcus 1984, Milne and Whalley, 2001, Berger et al., 2008). Banks may also need to hold excess capital in order to signal soundness to the market, to target an external credit rating, or as financial slack to take advantage of future profitable investment opportunities (Berger et. al 1995; BCBS 1999,). From a regulatory perspective, it is important to understand whether capital requirements affect the capital structure in banks, i.e. if changes in capital requirements have an effect on banks' capital ratio, or whether they only impact the voluntary capital buffer banks hold in excess of the minimum capital requirement.

The empirical literature on time-varying capital requirements is scarce because of the limited actual experience with these requirements prior to Basel III. A notable exception is the dynamic provisioning introduced in Spain in 2000. Jiménez et al. (2015) investigate the dynamic provisioning and its effects on credit supply and find that if helped smooth the Spanish credit cycle. The second exception is the UK where capital requirements for the past two decades have been set differently over time and across banks, reflecting changes in bank-specific risks. Several studies incorporate this framework to investigate the impact of time-varying capital requirements on bank behavior. Alfon et al. (2005) and Francis and Osborne et al. (2012) find that UK banks rebuild between $0.25-0.50 \%$-points of their initial buffer following a $1 \%$-point change in capital requirements while Bridges et al. (2015) observe a 0.40\%-points rebuild within the first year. Regarding the effect of capital requirements on bank lending, Francis and Osborne (2012) show that banks tend to adjust the risk composition of their asset portfolio rather than the volume of loan and asset portfolios. Aiyar et al. (2014) focus on how capital requirements affect loan supply to firms in the UK, and whether increases in capital requirements 'leak' in the sense that foreign branches can offset reductions in lending by regulated UK banks. They find that regulated UK 
banks reduce lending to firms by $6-8 \%$ in response to a $1 \%$-point increase in capital requirements, but that unregulated foreign banks partly step up by increasing lending instead. In a related study, Bridges et al. (2015) show that capital requirements set at the bank group (consolidated) level have an heterogeneous effect on lending to different sectors in the economy. They estimate that a $1 \%$-point increase in capital requirements on average cut - in descending order - loan growth to commercial real estate with $8 \%$, other corporate loans with $4 \%$, household secured lending with $1 \%$, and unsecured household lending with $0.5 \%$. Aiyar et al. (2016) shed light on the interaction between monetary policy and time-varying capital requirements by investigating how loan supply responds to monetary policy and bank minimum capital requirements when the two instruments are deployed jointly in the UK. They find that tightening of either capital requirements or monetary policy reduces the supply of lending but that there is little evidence of interaction between the two policy instruments.

Most studies outside Spain and the UK focus either on the introduction of Basel I or the increase in capital requirement by the European Banking Authority (EBA) for large European banks in 2012. It is important to keep in mind that the introduction of Basel I also implied more risk sensitive capital requirements and the inclusion of off-balance-sheet exposures in the calculation of the capital ratio in addition to the change of the capital requirement. The increase in capital requirement by the European Banking Authority (EBA) in 2012 was unexpected by the market though also introduced in connection with the Capital Exercise of 2011-2012 to restore confidence in the banking sector during the European sovereign debt crisis. A survey by the Basel Committee on Banking Supervision (BCBS) (1999) of more than 130 research papers on the effects of Basel I shows that banks raise new capital or use retained earnings in economic boom periods while they cut back lending in economic troughs. It suggests that the introduction of Basel I may have restricted bank lending and exacerbated the cyclical downturns in Japan and 
the US in the early 1990's. Messonier and Monks (2015) study the announcement by the European Banking Authority (EBA) of a core Tier 1 capital requirement of 9\% for large European banks in 2012. They find that banks which were forced to increase their core Tier 1 capital ratio by $1 \%$ had loan growth that was $1.2 \%$ lower than a group of unconstrained banks. Similarly, Gropp et al. (2016) also observe that credit supply decreased which implied negative real effects for more bank dependent borrowers of affected banks.

Finally, Behn et al. (2016) use the differential introduction of Basel II in German banks to identify the effect of loans granted under the internal ratings-based (IRB) approach compared with those granted under the standard approach when banks using the IRB approach faced an increase in capital charges following the failure of Lehman Brothers in September 2008. They find that the effect on loans granted is different for the different types of risk approaches. De Jonghe et al. (2016) investigate time-varying bank specific capital requirements in Belgium and observe a reshuffling of banks' loan portfolios driven by smaller, riskier, or less profitable banks affecting mostly large, risky and low borrowing cost firms. Fraisse et al. (2017) impute capital requirements for banks and find that a $1 \%$-point increase of these results in a $10 \%$ decline in lending.

\subsection{INSTITUTIONAL DETAILS}

Danish banks were required to implement the 1988 Basel Accord (Basel I). This required that banks had to comply with a minimum capital requirement of $8 \%$ of risk-weighted assets (RWA), like for banks in other countries. The introduction of Basel II in 2007, though, was unique in Denmark. First, on top of the minimum $8 \%$ capital requirement banks have to comply with an individual capital need. This individual capital need is specific to each bank and varies over time. It allows to better address bank-specific risk such as e.g. concentration or interest rate 
risk. Each bank calculates its own individual capital need, however, following guidelines set forth by the Danish FSA. The individual need is reported to the FSA quarterly and reflects changes in the risk of each bank over time. A (intentional or unintentional) misreporting implies severe charges for the bank and is also publicly announced by the FSA on its website. As part of its task in ensuring compliance with banking regulations, the FSA regularly assesses the validity of banks' individual capital need through off-site surveillance and on-site inspections. Second, banks in Denmark are required to publicly disclose their individual capital need in annual and interim reports since 2010. The reason behind this publication requirement was to increase the transparency of banks' risk profiles and allow investors to better be able to evaluate the adequacy of banks' solvency positions.

Another interesting feature of the Danish banking market is that the FSA changed its supervisory approach to a violation of a bank's individual capital ratio introduced in 2013. Until 2012, non-compliance with the individual capital need implied that the license to operate as a bank was withdrawn by the FSA unless capital was restored within a short period of time usually within a weekend. During our sample period, the Danish FSA closed several banks due to non-compliance with the individual capital need even when banks' total regulatory capital ratio was higher than the "regular" 8\% capital requirement (Danmarks Nationalbank, 2013). To our knowledge, Denmark is the only banking market to date which has implemented a time-varying bank-specific hard requirement for the capital ratio which is publicly known. However, from 2013 on the individual capital need was changed to a soft capital requirement for reasons of comparability with the supervisory approach of Basel II in other countries. This soft interpretation implies that non-compliance triggers various supervisory actions, e.g. increased monitoring from the FSA, restrictions on dividend payments etc., but does not imply that the 
banking license is immediately withdrawn. This is comparable to the enforcement of the countercyclical capital buffer in Basel III.

Accordingly, as shown in Table 1, the features of the market allow us to split our sample period into three sub-periods characterized by differences in disclosure as well as supervisory action following non-compliance with a bank's capital requirements.

[Insert Table 1 here]

The Danish banking market is characterized by a few large international groups and many small institutions. We investigate whether SIFIs differ from other banks. Systemically important financial institutions (SIFIs) are defined as banks with assets larger than $6.5 \%$ of GDP, or lending of more than $5 \%$ of total bank lending volume, or deposits of more than $5 \%$ of total bank deposit volume, over at least two consecutive years.

\subsection{METHODOLOGY}

The research question of our paper is how a bank's capital structure changes when the regulatory capital ratio requirement changes. The capital structure of a bank is determined by several choice variables at the same time. A bank's capital ratio is calculated as equity over riskweighted assets, i.e. the level of equity, the level of risks, and the level of assets enter into the calculation of the required capital ratio. Assuming that the management of a bank decides on one of these variables independently of all others seems to be a very strong assumption. We therefore employ a simultaneous equations approach to account for the possibility that bank policy decisions might not be orthogonal to each other. This implies that we estimate a system of structural equations. All dependent variables are explicitly taken to be endogenous to the system and are treated as correlated with the disturbances in the system's equations. For identification, we use the first lag of the dependent variables as instruments after having rejected a unit root for 
all variables in a Phillips-Perron test and autocorrelation in panel data by a Wooldridge test. This GMM estimator then calculates a weight matrix which is used in the second step of the estimation for the correlation structure of the equation disturbances.

In our analyses, we incorporate bank-specific time-varying capital requirements. This allows us to identify the bank-specific reaction to a change in the required capital ratio by incorporating bank and time fixed effects in all analyses. If all banks face the same increase in capital requirements (as e.g. in the counter-cyclical buffer of Basel III), the identification of how banks react to such changes becomes more challenging, as one would need to separate the effects on banks' behavior resulting from changes in the economy and changes in the counter-cyclical buffer. In our setting, we can control for time fixed effects, such as the macroeconomic situation, and study reactions to changes in capital requirements more clearly. In addition, our setting allows us to say something about how banks' reactions to changes in capital requirements are affected by changes in disclosure rules and the severity of consequences when breaching timevarying capital requirements.

\section{Data}

In our study, we include quarterly data from 2007 until mid-2014 provided by the Danish FSA on all banks operating in Denmark. This includes publicly available data such as accounting information as well as proprietary data such as the regulatory capital requirement for each bank in each quarter including periods of confidential disclosure of regulatory minima. Banks are anonymized but we have information on bank type available, e.g. if a bank is a SIFI or a mortgage bank.

We observe a considerable number of bank mergers and acquisitions (M\&A) over our sample period, not least due to the 2007-2009 financial crisis; Rangvid et al. (2013) provide a 
comprehensive account of the Danish financial crisis and how it affected Danish banks. We control for this in all analyses by including a dummy variable in the quarter when a merger or acquisition becomes effective. In addition, some banks switched to an internal ratings-based (IRB) approach to calculate risk-weights, as also examined for Germany in Behn et al. (2016). This creates large variation in banks' capital structure and we account for this via a dummy variable which is one in the period when the IRB models are introduced by the bank. ${ }^{5}$ Our final sample includes 128 banks with on average 23 quarterly observations of a bank.

Table 2 shows in Panel A descriptive statistics of the variables we use. The table shows that the average capital requirement is $10.24 \%$ while banks have on average an actual capital ratio of $18.57 \%$, reflecting that many banks hold a substantial capital buffer above the regulatory minimum as also confirmed for the US in Berger et al. (2008). Bank capital growth over our sample period is $0.389 \%$ while loan growth is $-0.054 \%$. The risk of bank's assets, defined as riskweighted assets (RWA) over total assets, is $76 \%$ and decreases over our period. Panel A also shows a positive growth of Tier 1 capital and a slight increase of banks' leverage. The average bank in Denmark has total assets of DKK77,100 mn. (about USD12,850 mn.). As mentioned before, the Danish banking market is characterized by many small and some large banks. This is reflected in the large difference between the mean and the median of total assets. Banks have on average a return on assets of $0.128 \%$, loan reserves of $4 \%$ and charge-offs of $0.49 \%$, while the net interest income is $1.824 \%$. $1.8 \%$ of our observations are related to M\&A of banks and $0.3 \%$ to the introduction of the IRB approach. In $2.3 \%$ of quarterly observations, the FSA visits the bank on-site and issues an injunction due to incorrect calculation or underestimation of risks.

[Insert Table 2 here]

\footnotetext{
${ }^{5} \mathrm{We}$ also run all regressions excluding M\&A and IRB introduction periods. The results are very comparable.
} 
Panel B of Table 2 shows descriptive statistics of variables over the periods 2007 to 2009 , 2010 to 2012, and 2013 until the end of our observation period, in line with the different disclosure and supervisory action regimes shown in Table 1. We observe that most variables changed significantly from the first to the second time interval. The changes to the third interval are mostly small and insignificant. Overall, the panel shows that capital requirements increased substantially for banks over our period. Banks significantly reduced their asset risk over time while loans and loan commitments decreased and liquid assets increased only from the first to the second time period and remained rather stable thereafter. This indicates a reshuffling of assets in banks' portfolio towards those with a lower risk weight and might also be attributable to other regulatory arbitrage mechanisms banks implement such as "carry trades" as shown in Acharya and Steffen (2015). The effects from the financial crisis and the subsequent changes in monetary policy are reflected in increasing loan loss reserves over time as well as decreasing net interest income.

Figure 1 shows the level of banks' regulatory capital requirement using the period 2013:Q4 as an example. We observe a large variation among banks with only three banks having to comply with the regulatory minimum in Basel II of $8 \%$. Most banks have to fulfil a minimum requirement between 9 and 12\%, where the maximum requirement is $19 \%$ for one bank. Figure 2 depicts the number and size of the changes in capital requirement over our sample period. It shows that the variation is large with most changes ranging from -1 to +1 percentage point. However, it also reveals that some changes are substantial. Overall, we include 1,652 changes in bank-specific capital requirements in our study.

\section{[Insert Figure 1 and Figure 2 here]}

Our data allows us to distinguish between positive and negative changes in capital requirement. As mentioned earlier, we expect that banks can much easier address a decrease than 
an increase. Figure 3 shows the number of increases and decreases in each year. It reveals that during the financial crisis period and its aftermath, the number of increases was higher than the number of decreases. This is intuitive. However, from 2012 on we observe that the number of increases and decreases is roughly the same where in (the first half) of 2014 the number of decreases outnumbers the number of increases in capital requirement reflecting the recovery of the Danish banking market.

[Insert Figure 3 here]

\section{Results}

This section presents the multivariate results. First, we show the impact of a change in the required capital ratio on its direct components: equity, loans, and risk-weighted assets. We also split between positive and negative changes. Thereafter, we investigate further channels, such as the capital buffer and liquid assets, and we go further into detail with respect to the equity and the loan channel. This is followed by results on the precision of the changes in regulatory capital requirement. Then, we study SIFIs. Finally, the impact of changes in regulatory capital requirement is analyzed for all relevant channels distinguishing between different disclosure and supervisory action regimes.

\subsection{BANK CAPITAL RATIO AND ITS COMPONENTS}

In the first part of our multivariate analyses, we investigate the effect of a change in the regulatory capital requirement in general, i.e. without distinguishing between hikes and reduction, on its main components: equity, loans, and risk-weighted assets. We are interested in understanding if banks adjust their capital ratio at all and if they do so, how. While regulators and policymakers most likely would like banks to change the numerator of the capital ratio, i.e. the 
level of capital, prior literature suggests that banks rather adjust it using the components of its denominator, i.e. the amount or riskiness of loans and other exposures (e.g., Aiyar et al., 2014, 2016; Acharya and Steffen, 2015; Behn et al. 2016; De Jonghe et al., 2016). Table 3 shows the results from our simultaneous equation estimation. We estimate four equations simultaneously. The dependent variables are, respectively, the quarterly percentage change of the capital ratio, growth in bank capital, growth in loans, and the change in the riskiness of banks' assets. We are primarily interested in the coefficient of each equation describing how the dependent variable reacts to a change in the capital requirement. All equations include bank control variables as shown in the table as well as bank and quarter fixed effects. ${ }^{6}$

[Insert Table 3 here]

The table confirms that banks adjust their capital ratio by adjusting the components of its denominator. We observe a statistically significant negative coefficient for loan growth and for asset risk while the coefficient for capital growth is insignificant. This means that, overall, banks adjust their capital ratio when the capital requirement is changed. They do so by changing the amount of loans and the riskiness of the assets. Banks do not seem to adjust the amount of capital. As we will show next, there are important differences, however, in how banks adjust to positive and negative changes in capital requirements.

Before turning to the effects of hikes and reductions in capital requirements, we briefly note that the control variables behave as expected. Banks with a positive return on assets are able to accumulate more capital. This increases the capital ratio. A high charge-off rate reduces the exposure to risky loans. This leads to a higher capital ratio. M\&As increase bank capital as well

\footnotetext{
${ }^{6}$ In unreported robustness tests, we additionally include lagged changes (up to one year) in the capital requirement to account for a more gradual adjustment of banks' capital structure. The lagged changes in requirement are insignificant in almost all cases. This means that banks adjust the bulk of their capital structure in the same quarter as the capital requirement is changed. We also did a robustness check where we replace quarterly fixed effects with GDP growth and the level of the interest rate. All conclusions remain unaffected.
} 
as loan volume but have no effect on the risk of bank assets. The introduction of the IRB approach by some banks results in a higher capital ratio driven by a decrease in asset risk.

In Table 4, we split changes in regulatory capital requirement into positive and negative ones. It is much easier for banks to address a decrease in capital ratio than an increase. Basically, if the capital requirement is reduced, banks do not have to do anything. They will have a larger capital buffer, and they can decide to do something, but do not have to. On the other hand, when the capital requirement is increased, banks will have to do something, when the capital requirement is binding. In cases of binding constraints, they will have to increase capital, adjust the asset volume or the riskiness thereof. Basically, it is easier to adjust to reductions than to hikes, and for this reason we might find different reactions of banks depending on the sign of a change in regulatory capital requirement. Note that we include decreases in capital requirement in absolute value. This allows for a direct comparison of the sign of the effect of positive and negative changes on the dependent variable.

\section{[Insert Table 4 here]}

The table confirms that banks use different channels to adjust their capital ratio depending on the sign of the change in regulatory requirement. When the capital requirement is increased by $1 \%$-point, banks increase their capital ratio by $0.19 \%$-points. They do so by adjusting the risk of their assets. In other words, when facing higher capital requirements, banks reshuffle their portfolio towards assets with lower risk weights while the total volume of e.g. loans does not change. This increases the capital ratio. This behavior is intuitive and adds to prior findings on regulatory arbitrage of banks (Acharya and Steffen, 2015). It is also related to more general findings on the reshuffling of bank loan portfolios (e.g.; Dell'Ariccia et al., 2017). It argues for banks trying to preserve their market power and presumably also parts of their interest income despite the increase in capital requirement. Regarding the insignificant coefficient for capital 
growth, we acknowledge that our sample period includes several instances of market stress. It might have been difficult for banks to obtain external equity capital when the regulatory capital requirement increases during stress periods. Table 4 also shows that decreases in regulatory capital requirement induce banks to lend more without changing the composition of their asset risk. This decreases their capital ratio. In addition, we observe a weakly significant negative growth of bank equity which might be related to (higher) dividend payments when the capital requirement decreases.

Overall, we find that banks adjust their capital ratio in response to both increases and decreases of the regulatory requirement. Banks adjust their capital ratio stronger when capital requirements are reduced. Banks also use different channels for the adjustment depending on the sign of the change in requirement. To fully understand the adjustment process in bank capital structure, we incorporate additional potential channels.

\subsection{BANK CAPITAL RATIO AND FURTHER CHANNELS}

Bank management has several options available to address a change in the regulatory capital requirement. Most obviously, the components of the ratio of bank capital can be adjusted. However, another factor which might also be considered is the buffer between actual and regulatory capital ratio (e.g., Berger et al., 2008). Table 2 shows that the buffer is 9\%-points on average for the banks in our sample implying a lot of flexibility. This implies that, theoretically, banks on average do not have to adjust their capital ratio at all when the regulatory requirement changes. Their capital buffer is, on average, large enough to cover increases in capital requirements. We also would like to better understand the equity and asset risk channel. Regarding equity, we are especially interested in the question of whether banks issue new equity when the regulatory capital requirement increases. If banks raise new equity, this would be 
reflected by an increase in Tier 1 capital. As mentioned before, this is presumably what is intended by regulators and policy makers. It would be accompanied by a decrease in bank leverage, calculated as assets over Tier 1 capital. This is also interesting from the perspective of Basel III where the leverage ratio is included to constrain excess leverage and protect against risk model failures of banks. Regarding asset risk, we have to account for the composition of assets. In most banks, the bulk of these consists of loans with a positive risk weight. However, especially in crisis periods banks build up substantial portions of liquid assets such as cash, central bank reserves or government bonds which might even be used for regulatory arbitrage (Acharya and Steffen, 2015). Accordingly, a change in RWA could be accompanied by a strong increase in liquid assets, which have zero risk weight, and be unrelated to the risks in the bank's loan portfolio. For these reasons, we add the capital buffer, the growth in Tier 1 capital, the leverage ratio, and the change in liquid asset to our main variables and include them in our simultaneous equations estimation. Table 5 shows the results.

[Insert Table 5 here]

Panel A shows the general effect of a change in regulatory requirement. We observe that banks adjust their capital ratio by changing the volume of loans, asset risk, the capital buffer and bank leverage. We split again the change in regulatory capital requirement into increases and decreases and report the results in Panel B of Table 5. It again confirms that banks use different channels for the adjustment of their capital ratio depending on the sign of the change in regulatory requirement. Panel B shows that an increase in the regulatory capital requirement results in an increase of a bank's capital ratio. The capital ratio is increased due to a decrease in asset risk. Furthermore, banks reduce their capital buffer by $82.6 \%$ of the increase in capital requirement. Note that the coefficients for the increase in capital ratio and the decrease in capital buffer almost exactly add up to one. The Panel does not reveal any effects for total bank capital, 
Tier 1 capital, or bank leverage. Furthermore, neither the volume of loans nor the portion of liquid assets is affected arguing for a reshuffling of loans towards those with lower risk weights. Accordingly, an increase in the regulatory capital requirement results in a more resilient bank with lower asset risk but it also implies that the capital buffer is reduced. A lower buffer implies that the distance to default has decreased, i.e. the bank has become less resilient. ${ }^{7}$ In sum, the overall effect of an increase in the required capital ratio on bank resilience is not entirely clear. For a decrease in regulatory capital requirement, Panel B reveals that banks reduce their capital ratio by reducing their Tier 1 capital. This results in higher bank leverage. Banks also grant more loans. The decrease in Tier 1 capital is also reflected in a weakly statistically significant effect for total capital growth and might be driven by (higher) dividend payments. Banks again use the flexibility of the capital buffer and further increase it when the capital requirement decreases. Accordingly, a decrease in the regulatory capital requirement results in a less resilient bank with less equity and higher leverage but at the same time implies an increase in the capital buffer and loan volume.

Supervisors, regulators and policy makers around the world try to foster the growth of corporate loans since the global financial crisis of 2007 to 2009. In the last part of this section, we therefore investigate if a decrease in the regulatory capital ratio requirement might be used as a policy instrument for firm loan growth. For this purpose, we split loans into retail, corporate, and public institution loans. We only have annual data for these available and therefore analyze them separately from the previous analysis using OLS regressions. ${ }^{8}$ We aggregate all data to the year level and analyze the effect of a change in capital requirement on loan types. Table 6 shows the results.

\footnotetext{
${ }^{7}$ Note that this interpretation assumes that a bank defaults when it violates the regulatory capital requirement.

${ }^{8}$ Because of the low number of observations for the growth of loans to public institutions, we refrain from implementing our simultaneous equations approach.
} 
[Insert Table 6 here]

We find that the results in Table 5 derive from the effect on loans to firms. A decrease in the regulatory capital requirement results in a growth of firm loans and has no effect on retail loans and loans to public institutions. The effect is remarkable. A decrease of the regulatory capital requirement of only $0.25 \%$-points implies an increase in corporate loans of $3.24 \%$. Accordingly, the negative effect on bank resilience from a decrease in capital requirement is accompanied by a substantial increase in bank lending to firms and suggests the regulatory capital ratio to also be a relevant policy instrument.

Overall, our results empirically illustrate a tradeoff between bank resilience and a fostering of the economy through more bank lending using banks' capital ratio as policy instrument. When the supervisor increases the capital requirement, banks end up being more robust, as they increase their capital ratio. They do so by reducing their asset risk, by reshuffling their loan portfolio. Their capital buffer also decreases, though. A decrease in the capital requirement implies that loans to firms increase and the capital buffer increases but also that banks become more risky due to a decrease in Tier 1 capital and an increase in bank leverage.

\subsection{PRECISION OF CHANGES IN CAPITAL REQUIREMENT}

The bank-specific capital requirement is calculated by banks themselves. It reflects risks not captured by the standard capital requirement. Given that banks calculate the requirement themselves, and report the calculated number to the FSA, a concern might be that banks have considerable flexibility in calculating the requirement. This is not the case. Banks face severe charges when (intentionally or unintentionally) misreporting their capital ratio requirement to the regulator and the misreporting is publicized on the FSA's website with potentially detrimental effects on the bank's reputation. A concern might still be that these repercussions are too small to 
hinder a misreporting by the banks. It would imply that the changes in capital requirement which we incorporate in our analyses are imprecise.

The information about on-sites visits of the FSA where a misreporting by a bank was detected and an injunction issued is included in our data. We hypothesize that if banks systematically misreported their regulatory capital requirement, we should observe that an unexpected on-site visit from the FSA, which results in an injunction for the bank due to incorrect calculation or underestimation of risks, should reveal differences in banks' adjustment of their capital ratio in response to a change in capital requirement. We therefore define a dummy variable which is one in the quarter when the FSA inspects a bank and detects a deviation from standards defined by the FSA for the calculation of the bank's individual capital requirement and zero otherwise. We interact the change of the capital requirement with this variable to test for differential effects in capital structure adjustment when a misreporting is detected. By definition, the detection of a miscalculation or misreporting of the individual capital ratio requirement implies an immediate adjustment of the capital requirement. Table 7 shows our findings using all dependent variables which we have shown to be relevant for capital structure adjustment. ${ }^{9}$

[Insert Table 7 here]

It reveals that there are no differences in bank capital structure adjustment when the FSA detects a miscalculation or misreporting of the individual capital need. None of the coefficients of the interaction term are significant. This argues for the changes in capital requirement to be precise and is intuitive given that the capital buffer of banks is about $9 \%$-points on average as shown in Table 2. Our results show that the FSA and banks seems to mostly differ in their definition of equity capital which substantially decreases when the FSA publicly reports an injunction and results in higher bank leverage.

${ }^{9}$ We do this for reasons of brevity. Including all equations from Table 5 does not change any of the results. 


\subsection{SYSTEMICALLY IMPORTANT FINANCIAL INSTITUTIONS}

Recent banking regulation, that is Basel III, regulates large systemically important institutions (SIFIs) more stringent than smaller banks. SIFIs might react differently to changes in capital requirement because of being too-big-to-fail (e.g.; Freixas and Rochet, 2013). Accordingly, moral hazard might be increasing with banks' size. However, larger banks which operate to a larger degree internationally may also have better access to external capital which implies greater flexibility in handling changes in capital requirements compared to small banks. In order to investigate potential differing effects of a change in capital requirement on bank capital structure between SIFI and smaller banks we define a dummy variable which is one when a bank is deemed as a SIFI by the FSA and zero otherwise and interact it with the change in capital requirement. ${ }^{10}$ Table 8 shows the results. ${ }^{11}$

[Insert Table 8 here]

Panel A confirms our previous finding that banks in general adjust their capital ratio when the capital requirement changes by changing their loan volume, asset risk, capital buffer and leverage. SIFIs do not appear to be using different channels with the exception of loan volume. Differentiating between increases and decreases in the capital ratio requirement in Panel B shows that at least some SIFIs seem to have had access to external capital markets when their capital requirement increased. Both the coefficients for capital growth and Tier 1 capital growth as well as bank leverage are significant for the interaction term of increases in capital requirement and SIFI. This is in line with SIFIs' better access to equity markets. Panel B also shows that a decrease in capital requirement does not seem to have an effect on SIFI lending. This suggests that the capital requirement would be a less useful policy instrument for the fostering of lending

\footnotetext{
${ }^{10}$ The definition of SIFIs in Denmark is provided in Section 2.2. As of 2017, the following banks are defined to be SIFIs: Danske Bank, Nykredit Realkredit, Nordea Bank Danmark, Jyske Bank, Sydbank, and DLR Kredit.

${ }^{11}$ Note that the base effect for SIFI is already subsumed in the bank fixed effects.
} 
of SIFIs. However, we interpret our results on SIFIs with caution given the rather low statistical power due to the low number of observations for these.

\subsection{DISCLOSURE AND SUPERVISORY REGIME}

In this section, we investigate two more policy changes unique to the Danish banking market. These are regulatory capital disclosure requirements for banks and "soft" versus "hard" capital requirements. Prior to 2010, banks had to disclose their capital requirement only to the Danish FSA. Since 2010:Q1 they have to disclose their bank-specific capital requirement publicly. This implies an increase in bank transparency and might strengthen the transmission mechanism of the regulatory requirement especially for increases in capital requirement. Banks might have to signal their strength to the market in response to the increase. Enhanced disclosure requirements are also an element of Basel III. Furthermore, Basel III also includes the countercyclical capital buffer. It is a "soft" requirement for banks implying that several supervisory actions are triggered when it is violated but the bank is not closed as it is the case with a "hard" requirement. Prior to 2013, the individual capital requirement in Denmark was a "hard" requirement and several banks were closed when breaching their individual capital requirement, even when their level of capital still exceeded the $8 \%$ hurdle generally applied in Basel II (Danmarks Nationalbank, 2013). In 2013, it was relaxed to a "soft" requirement to adjust the bank-specific capital requirement more towards the Pillar 2 approach used in other countries.

We define three different market regimes, in line with the differences in disclosure requirement and supervisory action, as shown in Table 1. The first regime ranges from 2007:Q1 until 2009:Q4 with confidential disclosure and a "hard" capital requirement, the second from 2010:Q1 until 2012:Q4 with public disclosure and a hard requirement, and the third one from 2013:Q1 until the end of our sample period in 2014:Q2 with public disclosure of the capital 
requirement and the capital ratio requirement being a "soft" threshold. We define three indicator variables for each of these three periods and use them to split our variable of the change in regulatory capital requirement between the three regimes. We include these three interaction terms in our simultaneous equations estimation approach. ${ }^{12}$ Table 9 shows the results.

[Insert Table 9 here]

In Panel A, we observe that effects are statistically as well as economically strongest in the second regime where disclosure was confidential and the capital requirement was "hard". Our previous results show that banks employ different channels in response to a change in capital requirement depending on the sign of the change. We therefore further split the changes in capital requirement between positive and negative changes and investigate their effects during the three regimes in Panel B. It shows that especially between the first and the second regime differences are only marginal. ${ }^{13}$ In both regimes banks change their capital ratio when the regulatory requirement changes. In contrast, during the third regime banks use the capital buffer to a much higher degree both for increases and decreases of the requirement while their actual capital ratio does not change at all. Accordingly, Panel B of Table 9 indicates that banks respond stronger to "hard" regulatory requirements. Differences in disclosure requirements seem to have no substantial differential effects on banks.

\section{Conclusion}

We investigate the effect of changes in capital requirements on banks' capital structure using proprietary data from the Danish FSA on the full population of banks in Denmark. Our findings are relevant from a policy perspective as they illustrate a tradeoff between bank

\footnotetext{
${ }^{12}$ Note that the base effects of the three periods are already subsumed by the quarter fixed effects.

${ }^{13} \mathrm{We}$ also test the statistical difference of coefficients between the periods and do not find any significances indicating that the coefficients are statistically the same.
} 
resilience and a fostering of the economy through higher bank lending using the capital ratio as a policy instrument. Our main findings are that an increase in the capital ratio requirement results in more resilient banks because banks decrease asset risk. However, banks also reduce the buffer between the actual and regulatory capital ratios. A decrease in the capital requirement implies more lending to firms. This is obviously desirable in crisis times. The downside is that it is accompanied by higher bank leverage due to a lower amount of Tier 1 capital. Our findings imply that the counter-cyclical capital buffer in Basel III might benefit from some adjustment. In economically good periods, when banks are supposed to increase their buffer, they might decrease asset risk to confirm with the higher capital requirement. This could imply that for example younger firms which are often riskier are cut off from the lending market. Furthermore, banks might only reduce the buffer between actual and regulatory capital ratio, which is against the general idea of the counter-cyclical capital buffer. In crisis times, however, when banks are supposed to reduce their counter-cyclical capital buffer, they might also lend more, which is one of the desired goals of the regulator. This comes at the cost of higher bank leverage and less core capital, though, implying less resilient banks. Finally, we observe that effects are strongest in an environment where the supervisor acts "hard" by closing banks when these breach their requirement. This suggests that the counter-cyclical capital buffer in Basel III might be less effective than currently intended because it is only a "soft" requirement for banks.

Our work provides several avenues for future research. It would be interesting to have more granular data on the channels of banks' adjustments. This would for example allow for a further investigation of the reshuffling of loans we observe when capital requirements increase. It argues for market separation in the loan market. Borrowers with high credit risk might be cut out of the market while loans might be in excess supply for borrowers with low credit risk. Furthermore, most studies so far focus only on increases in capital ratio. Our results indicate that 
bank capital requirements are not only a tool to increase bank resilience but might also be used as policy instrument when decreasing. More research is needed here to better understand these mechanisms.

\section{References}

Acharya, V., \& S. Steffen (2015). The "Greatest" Carry Trade Ever? Understanding Eurozone Bank Risks. Journal of Financial Economics 115(2), 215-236.

Admati, A. R., DeMarzo, P. M., Hellwig, M. F., \& Pfeiderer, P. (2013). Fallacies, irrelevant facts, and myths in the discussion of capital regulation: Why bank equity is not expensive. Stanford University, Graduate School of Business.

Aiyar, S., Calomiris, C. W., \& Wieladek, T. (2014). Does macro-prudential regulation leak? evidence from a UK policy experiment. Journal of Money, Credit and Banking 46(1), 181-214.

Aiyar, S., Calomiris, C. W., \& Wieladek, T. (2016). How does credit supply respond to monetary policy and bank minimum capital requirements? European Economic Review 82, 142165.

Alfon, I., Argimón, I., \& Bascuñana-Ambrós, P. (2005). How individual capital requirements affect capital ratios in the UK banks and building societies? Banco de España.

Basle Committee on Banking Supervision (BCBS) (1999). Capital requirements and bank behavior: The impact of the Basle Accord. BIS working paper No. 1 - April 1999.

Behn, M., R. Haselmann, \& P. Wachtel (2016). Procyclical Capital Regulation and Lending. Journal of Finance 71(2), 919-956.

Berger, A. N., Herring, R. J., \& Szegö, G. P. (1995). The role of capital in financial institutions. Journal of Banking \& Finance 19(3-4), 393-430.

Berger, A.N., R. DeYoung, M.J. Flannery, D. Lee, \& Ö. Öztekin (2008). How Do Large Banking Organizations Manage Their Capital Ratios? Journal of Financial Services Research 34, 123-149.

Bordo, M., Eichengreen, B., Klingebiel, D., Martinez-Peria, S. (2001). Is the crisis problem growing more severe? Economic Policy 16(32), 51+53-82.

Bridges, J., Gregory, D., Nielsen, M., Pezzini, S., Radia, A., \& Spaltro, M. (2015). The impact of 
higher capital requirements on bank lending. Bank of England Working Paper no. 486.

Danmarks Nationalbank (2013) Financial Stability Report 2013.

De Jonghe, O., H. Dewachter, \& S. Ongena. (2016) Bank capital (requirements) and credit supply: Evidence from pillar 2 decisions. National Bank of Belgium Working Paper 303.

Dell'Ariccia, G., D. Kadyrzhanova, C. Minoiu, \& L. Ratnovski (2017). Bank Lending in the Knowledge Economy, IMF and Georgia State University Working Paper.

Fraisse, H., M. Lé, \& D. Thesmar (2017), The real effects of bank capital requirements. ESRB Working paper 47.

Francis, W. B., \& Osborne, M. (2012). Capital requirements and bank behavior in the UK: Are there lessons for international capital standards? Journal of Banking \& Finance 36(3), 803-816.

Freixas, X., \& Rochet, J. (2008). The microeconomics of banking, second edition. MIT Press.

Freixas, X., \& Rochet, J. (2013). Taming Systemically Important Financial Institutions. Journal of Money, Credit and Banking 45(1), 37-58.

Gropp, R., T. Mosk, S. Ongena, \& C. Wix (2016) Bank response to higher capital requirements: Evidence from a quasi-natural experiment, SAFE working paper 156.

Jiménez, G., Ongena, S., Peydro, J., Saurina, J. (2015). Macroprudential policy, countercyclical bank capital buffers and credit supply: Evidence from the Spanish dynamic provisioning experiments. Forthcoming, Journal of Political Economy.

Laeven, Luc and Fabian Valencia (2012). Systemic banking crises database: An update. IMF Working Paper No. 12/163.

Marcus, A. J. (1984). Deregulation and bank financial policy. Journal of Banking \& Finance $8(4), 557-565$.

Mésonnier, J. and Monks, M. (2015). Did the EBA capital exercise cause a credit crunch in the Euro Area? International Journal of Central Banking 11(3), 75-117.

Milne, A., \& Whalley, A. (2001). Bank capital regulation and incentives for risk-taking. Cass Business School Research Paper.

Rangvid, J., N.K. Frederiksen, J. Galbo, A. Grosen, H.F. Jensen, P. Møgelvang-Hansen, B. B. Poulsen, P. Schütze, J. Thomsen, C. Ølgaard, F. Østrup (2013). The financial crisis in Denmark - causes, consequences, and learnings. Report to the Danish government. Danish Ministry of Business and Growth.

Reinhart, C.M., Rogoff, K.S. (2014). Recovery from financial crises: Evidence from 100 
episodes. American Economic Review 104(5), 50-55.

Schularick, M., Taylor, A.M. (2012). Credit booms gone bust: Monetary policy, leverage cycles, and financial crises, 1870-2008. American Economic Review 102(2), 1029-1061.

Thakor, A. V. (2014). Bank capital and financial stability: An economic trade-off or a faustian bargain? Annual Review of Financial Economics 6(1), 185-223. 


\section{Figure 1}

Level of regulatory capital requirement

The figure depicts the number of banks with a certain regulatory capital requirement, stated on the $\mathrm{x}$-axis, in the period 2013:Q4.

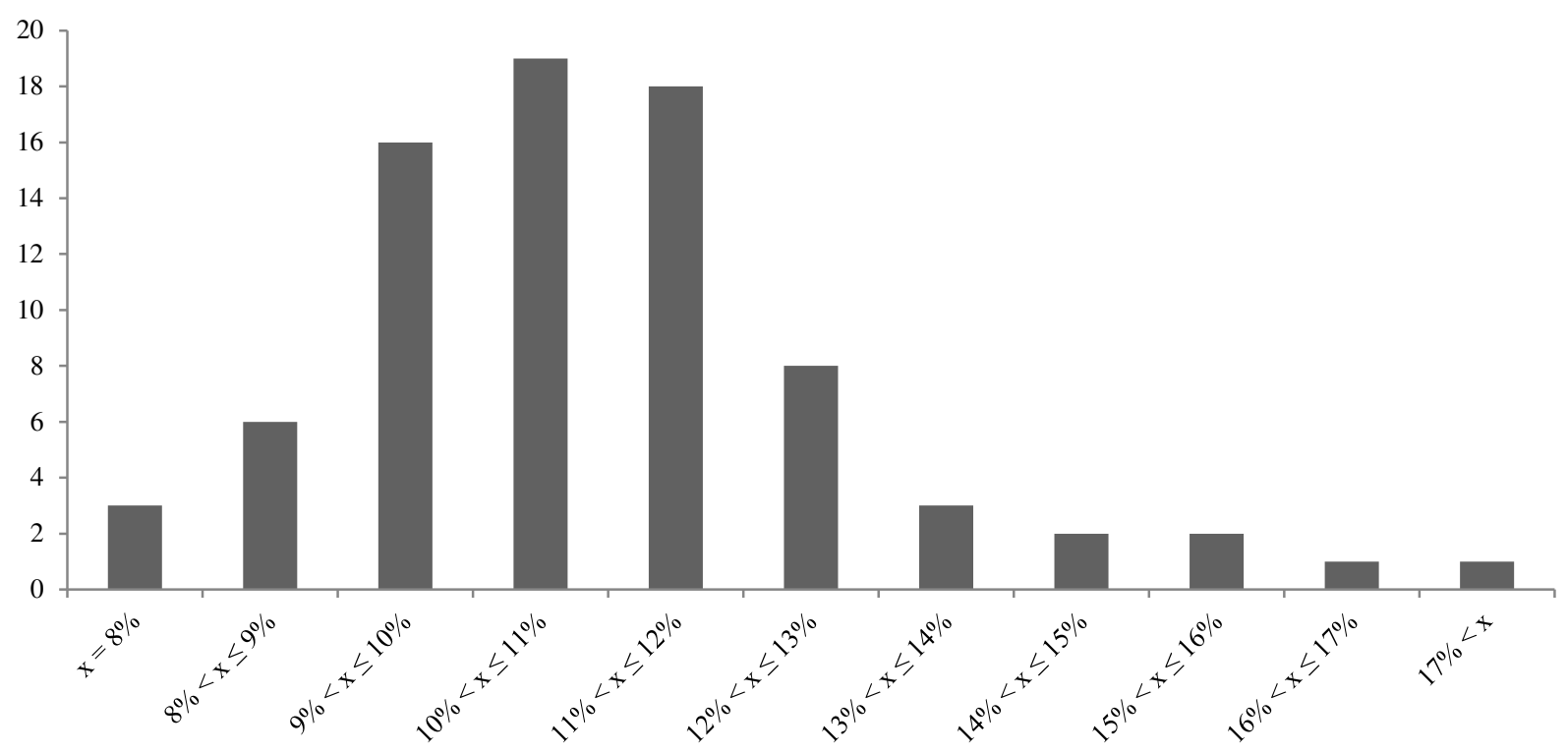

\section{Figure 2}

Changes in regulatory capital requirement

The figure shows the number of changes of the regulatory capital requirement, stated on the $\mathrm{x}$-axis, using the period 2007 until mid-2014.

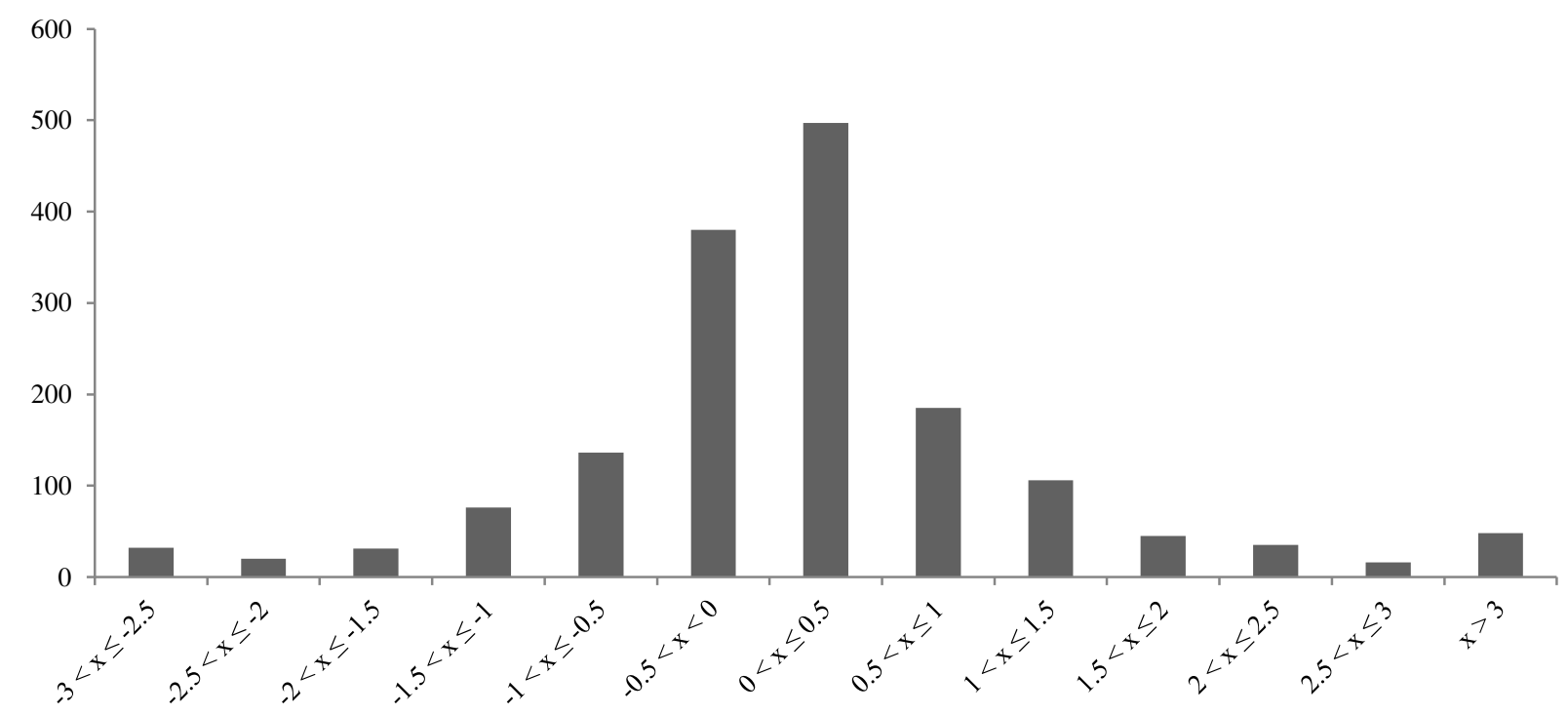


Figure 3

Number of increases and decreases in regulatory capital requirement over time

The figure shows the number of increases and decreases in regulatory capital requirement for each year.

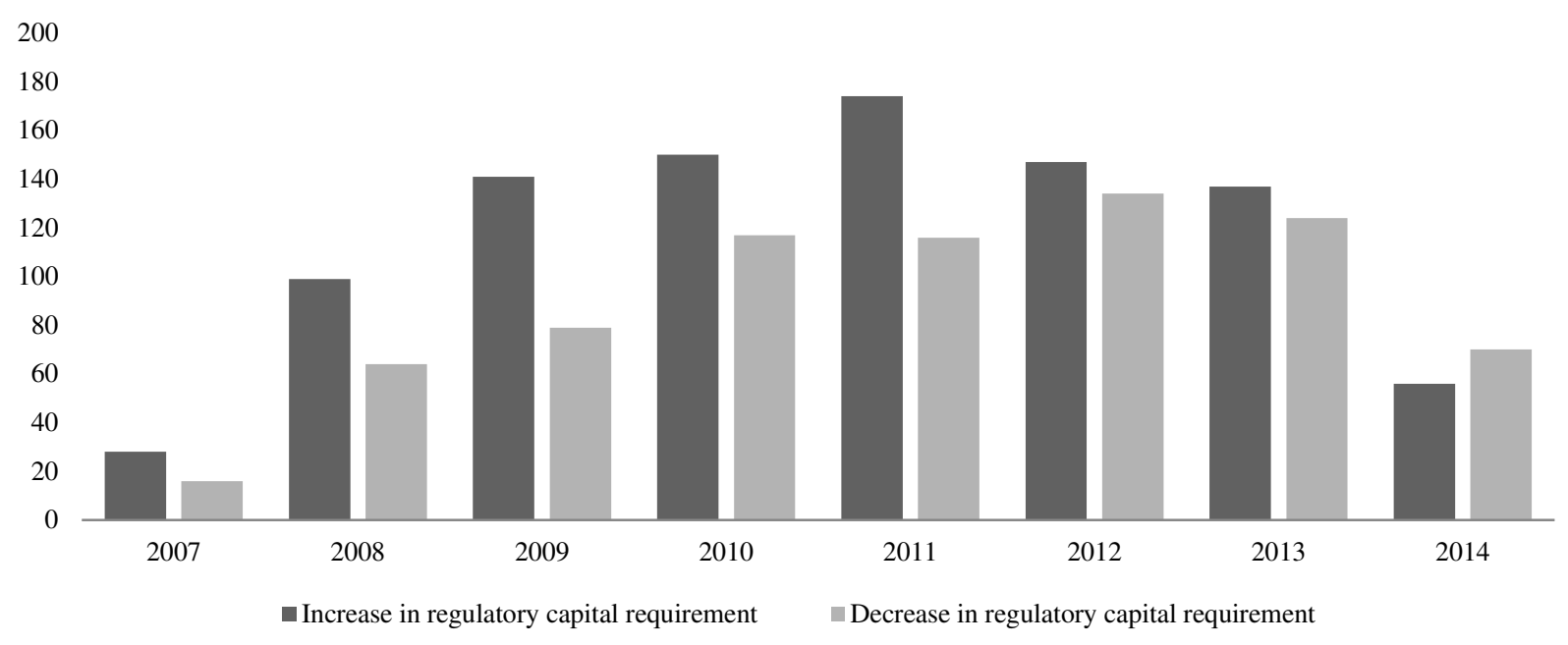




\section{Table 1}

Disclosure and Supervisory Action

The table shows the periods when banks have to disclose their capital ratio requirement only to the supervisor ("confidential") and when they have to disclose it publicly ("public"). It also shows the type of action of the supervisor in case the capital ratio is violated. "Hard" implies that the bank is closed when the capital ratio is violated, "soft" means the several supervisory actions are implemented but the bank is not closed when it breaches its ratio.

\begin{tabular}{lccc}
\hline & Regime 1 & Regime 2 & Regime 3 \\
& $2007-2009$ & $2010-2012$ & $2013-2014: \mathrm{Q} 2$ \\
\hline Capital Requirement Disclosure & Confidential & Public & Public \\
Supervisory Action & "Hard" & "Hard" & "Soft" \\
\hline
\end{tabular}


Table 2

Descriptive Statistics

The tables show descriptive statistics of variables for the 2007 to mid-2014 period. All variables are defined in Appendix A1.

\begin{tabular}{|c|c|c|c|c|c|c|}
\hline Panel A & Obs. & Mean & Std. Dev. & P5 & Median & P95 \\
\hline Capital Requirement & 2,932 & 10.238 & 3.629 & 8.000 & 9.600 & 14.200 \\
\hline$\Delta$ Capital Requirement & 2,743 & 0.113 & 0.857 & -1.056 & 0.000 & 1.600 \\
\hline Capital Ratio & 2,914 & 18.568 & 7.651 & 11.200 & 17.000 & 31.500 \\
\hline$\Delta$ Capital Ratio & 2,744 & 0.117 & 2.091 & -2.600 & 0.100 & 3.100 \\
\hline Capital Growth & 2,743 & 0.389 & 7.583 & -11.082 & 0.087 & 13.462 \\
\hline Loan Growth & 2,929 & -0.054 & 6.531 & -9.852 & -0.068 & 8.877 \\
\hline Asset Risk & 2,932 & 75.879 & 24.319 & 29.883 & 77.394 & 114.843 \\
\hline$\Delta$ Asset Risk & 2,742 & -1.115 & 6.316 & -10.377 & -0.575 & 6.586 \\
\hline Capital buffer & 2,932 & 9.080 & 11.025 & 1.900 & 7.200 & 20.913 \\
\hline Tier 1 capital growth & 2,742 & 0.473 & 8.552 & -12.365 & 0.232 & 14.135 \\
\hline Leverage & 2,910 & 11.265 & 13.885 & 5.154 & 10.217 & 21.825 \\
\hline$\Delta$ Leverage & 2,743 & 0.008 & 1.398 & -1.860 & -0.007 & 2.138 \\
\hline Liquid Assets & 2,683 & 31.097 & 11.878 & 16.462 & 28.385 & 55.729 \\
\hline$\Delta$ Retail Loans & 526 & -3.904 & 18.069 & -34.593 & -3.618 & 25.974 \\
\hline$\Delta$ Firm Loans & 530 & -2.365 & 17.643 & -33.275 & -2.506 & 24.155 \\
\hline$\Delta$ Loans to Public Inst. & 152 & -2.650 & 28.964 & -48.819 & -5.427 & 52.027 \\
\hline Assets (in $2014 \mathrm{mn}$. DKK) & 2,932 & 77,100 & 296,000 & 327 & 4,568 & 420,000 \\
\hline RoA & 2,932 & 0.128 & 1.355 & -1.651 & 0.237 & 1.528 \\
\hline STD RoA & 2,747 & 1.321 & 1.219 & 0.253 & 1.047 & 3.198 \\
\hline Loan loss reserves & 2,931 & 4.023 & 4.362 & 0.117 & 3.171 & 11.307 \\
\hline Charge offs & 2,931 & 0.494 & 1.264 & 0.000 & 0.165 & 1.899 \\
\hline Net interest income & 2,932 & 1.824 & 1.298 & 0.288 & 1.627 & 3.833 \\
\hline M\&A & 2,932 & 0.018 & & & & \\
\hline IRB & 2,932 & 0.003 & & & & \\
\hline Mortgage Bank & 2,932 & 0.059 & & & & \\
\hline Savings Bank & 2,932 & 0.385 & & & & \\
\hline FSA on-site visit & 2,932 & 0.023 & & & & \\
\hline
\end{tabular}

\begin{tabular}{|c|c|c|c|c|c|}
\hline Panel B & $\begin{array}{c}2007-2009 \\
(1) \\
\end{array}$ & $\begin{array}{c}2010-2012 \\
(2) \\
\end{array}$ & $\begin{array}{c}2013-2014: \mathrm{Q} 2 \\
(3)\end{array}$ & $\Delta[(2)-(1)]$ & $\Delta[(3)-(2)]$ \\
\hline Capital Requirement & 9.350 & 10.740 & 11.287 & $1.390 * * *$ & $0.547 * *$ \\
\hline$\Delta$ Capital Requirement & 0.130 & 0.105 & 0.093 & -0.026 & -0.012 \\
\hline Capital Ratio & 17.610 & 19.501 & 18.733 & $1.890 * * *$ & $-0.767 * *$ \\
\hline Loan Ratio & 71.152 & 62.848 & 61.497 & $-8.304 * * *$ & -1.351 \\
\hline Asset Risk & 85.739 & 69.919 & 65.190 & $-15.820 * * *$ & $-4.728 * * *$ \\
\hline Capital buffer & 8.845 & 9.656 & 8.256 & $0.811^{*}$ & $-1.400^{* *}$ \\
\hline Leverage & 11.948 & 11.102 & 9.895 & $-0.845^{* * *}$ & -1.208 \\
\hline Liquid Assets & 27.232 & 34.116 & 33.805 & $6.883^{* * *}$ & -0.310 \\
\hline \multicolumn{6}{|l|}{ Bank-specific variables } \\
\hline Assets (in $2014 \mathrm{mn}$. DKK) & 69,200 & 79,000 & 92,800 & 9,800 & 13,800 \\
\hline RoA & 0.204 & 0.015 & 0.212 & $-0.189 * * *$ & $0.196^{* * *}$ \\
\hline STD RoA & 1.246 & 1.467 & 1.137 & $0.220 * * *$ & $-0.329 * * *$ \\
\hline Loan loss reserves & 2.044 & 5.089 & 6.496 & $3.045^{* * *}$ & $1.407 * * *$ \\
\hline Charge offs & 0.232 & 0.713 & 0.630 & $0.481 * * *$ & -0.084 \\
\hline Net interest income & 1.905 & 1.811 & 1.647 & $-0.094 *$ & $-0.164 * *$ \\
\hline
\end{tabular}




\section{Table 3}

The impact of changes in regulatory capital requirement on bank capital ratio and its components The table shows the second step of two-step GMM regression results of a simultaneous equations estimation regressing variables defined at the top of each column on control variables. All variables are used at the bank-quarter level and defined in Appendix 1. All equations include bank and quarter fixed effects. For the two-step GMM estimator, the first step estimates each equation via 2SLS using the first lag of the dependent variables as instruments, where a Fisher type unit root test based on the Phillips-Perron test rejects a unit root and a Wooldridge test rejects autocorrelation in panel data in all cases. A weight matrix is then calculated which is used in the second step of GMM. The dependent variables are taken to be endogenous to the system and treated as correlated with the disturbances in the system's equations. The statistical significance of results is indicated by $*=10 \%$ level, $* *=5 \%$ level and $* * *=1 \%$ level using heteroscedasticity-robust standard errors. t-statistics are shown in parentheses below coefficient estimates.

\begin{tabular}{|c|c|c|c|c|}
\hline Dependent Variable & $\Delta$ Capital Ratio & Capital Growth & Loan Growth & $\Delta$ Asset Risk \\
\hline \multicolumn{5}{|l|}{ CAPITAL REQUIREMENT } \\
\hline$\Delta$ Capital Requirement & $\begin{array}{c}0.393 * * * \\
(8.953)\end{array}$ & $\begin{array}{c}0.192 \\
(1.169)\end{array}$ & $\begin{array}{c}-0.390 * * * \\
(-3.037)\end{array}$ & $\begin{array}{c}-0.721 * * * \\
(-5.671)\end{array}$ \\
\hline \multicolumn{5}{|l|}{ BANK CHARACTERISTICS } \\
\hline $\log$ (Assets) & $\begin{array}{c}-0.815 * * * \\
(-3.341)\end{array}$ & $\begin{array}{l}1.546^{*} \\
(1.700)\end{array}$ & $\begin{array}{c}3.373 * * * \\
(4.733)\end{array}$ & $\begin{array}{c}-2.004 * * * \\
(-2.843)\end{array}$ \\
\hline RoA & $\begin{array}{c}0.388 * * * \\
(9.482)\end{array}$ & $\begin{array}{c}2.055 * * * \\
(13.464)\end{array}$ & $\begin{array}{c}0.623 * * * \\
(5.208)\end{array}$ & $\begin{array}{c}0.119 \\
(1.009)\end{array}$ \\
\hline STD RoA & $\begin{array}{c}0.206^{* * *} \\
(2.454)\end{array}$ & $\begin{array}{c}1.031 * * * \\
(3.290)\end{array}$ & $\begin{array}{c}0.251 \\
(1.021)\end{array}$ & $\begin{array}{c}0.286 \\
(1.176)\end{array}$ \\
\hline Loan loss reserves & $\begin{array}{c}0.003 \\
(0.145)\end{array}$ & $\begin{array}{c}-0.233 \text { *** } \\
(-2.620)\end{array}$ & $\begin{array}{c}-0.329 * * * \\
(-4.717)\end{array}$ & $\begin{array}{c}-0.111 \\
(-1.611)\end{array}$ \\
\hline Charge offs & $\begin{array}{c}0.124 * * * \\
(3.620)\end{array}$ & $\begin{array}{c}-0.140 \\
(-1.098)\end{array}$ & $\begin{array}{c}-0.401 * * * \\
(-4.018)\end{array}$ & $\begin{array}{c}-0.267 * * * \\
(-2.705)\end{array}$ \\
\hline Net interest income & $\begin{array}{c}0.107 \\
(1.268)\end{array}$ & $\begin{array}{c}-0.232 \\
(-0.735)\end{array}$ & $\begin{array}{l}-0.622 * * \\
(-2.518)\end{array}$ & $\begin{array}{l}0.575 * * \\
(2.351)\end{array}$ \\
\hline$M \& A$ & $\begin{array}{c}-0.526^{* *} \\
(-1.964)\end{array}$ & $\begin{array}{c}6.929 * * * \\
(6.933)\end{array}$ & $\begin{array}{c}10.297 * * * \\
(13.151)\end{array}$ & $\begin{array}{c}-0.135 \\
(-0.174)\end{array}$ \\
\hline IRB & $\begin{array}{c}4.334 * * * \\
(7.128)\end{array}$ & $\begin{array}{c}-1.630 \\
(-0.718)\end{array}$ & $\begin{array}{c}2.836 \\
(1.596)\end{array}$ & $\begin{array}{c}-13.958 * * * \\
(-7.937)\end{array}$ \\
\hline Constant & $\begin{array}{c}12.876^{* * *} \\
(3.243) \\
\end{array}$ & $\begin{array}{l}-18.496 \\
(-1.249) \\
\end{array}$ & $\begin{array}{c}-48.165^{* * * *} \\
(-4.151) \\
\end{array}$ & $\begin{array}{c}28.866^{* *} \\
(2.514) \\
\end{array}$ \\
\hline Number of Observations & 2,513 & 2,513 & 2,513 & 2,513 \\
\hline Adjusted R-squared & 0.199 & 0.226 & 0.273 & 0.155 \\
\hline
\end{tabular}




\section{Table 4}

The impact of positive and negative changes in regulatory capital requirement on bank capital ratio and its components

The table shows the second step of two-step GMM regression results of a simultaneous equations estimation regressing variables defined at the top of each column on control variables. $\Delta$ Capital Requirement+ includes the value of a change in capital requirement when it is positive and zero otherwise. $\mid \Delta$ Capital Requirement $-I$ includes the absolute value of a change in capital requirement when it is negative and zero otherwise. The control variables are the same as shown in Table 3. All variables are used at the bank-quarter level and defined in Appendix 1. All equations include bank and quarter fixed effects. For the two-step GMM estimator, the first step estimates each equation via 2SLS using the first lag of the dependent variables as instruments, where a Fisher type unit root test based on the Phillips-Perron test rejects a unit root and a Wooldridge test rejects autocorrelation in panel data in all cases. A weight matrix is then calculated which is used in the second step of GMM. The dependent variables are taken to be endogenous to the system and treated as correlated with the disturbances in the system's equations. The statistical significance of results is indicated by $*=10 \%$ level, $* *=5 \%$ level and $* * *=1 \%$ level using heteroscedasticity-robust standard errors. t-statistics are shown in parentheses below coefficient estimates.

\begin{tabular}{|c|c|c|c|c|}
\hline & $\Delta$ Capital Ratio & Capital Growth & Loan Growth & $\Delta$ Asset Risk \\
\hline \multicolumn{5}{|c|}{$\begin{array}{l}\text { CHANGE IN CAPITAL REQUIREMENT - } \\
\text { DIRECTION }\end{array}$} \\
\hline \multirow[t]{2}{*}{$\Delta$ Capital Requirement ${ }^{+}$} & $0.186^{* * *}$ & -0.052 & -0.114 & $-0.911 * * *$ \\
\hline & $(2.976)$ & $(-0.222)$ & $(-0.623)$ & $(-5.008)$ \\
\hline \multirow[t]{2}{*}{$\mid \Delta$ Capital Requirement $^{-} \mid$} & $-0.765 * * *$ & $-0.629 *$ & $0.885^{* * *}$ & 0.379 \\
\hline & $(-8.351)$ & $(-1.833)$ & (3.294) & $(1.426)$ \\
\hline Other Controls & Yes & Yes & Yes & Yes \\
\hline Number of Observations & 2,513 & 2,513 & 2,513 & 2,513 \\
\hline Adjusted R-squared & 0.205 & 0.226 & 0.274 & 0.156 \\
\hline
\end{tabular}




\section{Table 5}

The impact of changes in regulatory capital requirement on bank capital ratio - further channels The table shows the second step of two-step GMM regression results of a simultaneous equations estimation regressing variables defined at the top of each column on control variables. $\Delta$ Capital Requirement+ includes the value of a change in capital requirement when it is positive and zero otherwise. $\mid \Delta$ Capital Requirement $-I$ includes the absolute value of a change in capital requirement when it is negative and zero otherwise. The control variables are the same as shown in Table 3. All variables are used at the bank-quarter level and defined in Appendix 1. All equations include bank and quarter fixed effects. For the two-step GMM estimator, the first step estimates each equation via 2SLS using the first lag of the dependent variables as instruments, where a Fisher type unit root test based on the Phillips-Perron test rejects a unit root and a Wooldridge test rejects autocorrelation in panel data in all cases. A weight matrix is then calculated which is used in the second step of GMM. The dependent variables are taken to be endogenous to the system and treated as correlated with the disturbances in the system's equations. The statistical significance of results is indicated by $*=10 \%$ level, $* *=5 \%$ level and $* * *=1 \%$ level using heteroscedasticity-robust standard errors. t-statistics are shown in parentheses below coefficient estimates.

\begin{tabular}{lcccccccc}
\hline Panel A & $\begin{array}{c}\Delta \text { Capital } \\
\text { Ratio }\end{array}$ & $\begin{array}{c}\text { Capital } \\
\text { Growth }\end{array}$ & $\begin{array}{c}\text { Loan } \\
\text { Growth }\end{array}$ & $\begin{array}{c}\Delta \text { Asset } \\
\text { Risk }\end{array}$ & $\begin{array}{c}\text { Capital } \\
\text { Buffer }\end{array}$ & $\begin{array}{c}\text { Tier 1 } \\
\text { Capital } \\
\text { Growth }\end{array}$ & $\Delta$ Leverage & $\Delta$ Liquid Assets \\
\hline CAPITAL REQUIREMENT & & & & & & & & \\
$\Delta$ Capital Requirement & $0.329^{* * *}$ & 0.300 & $-0.407 * * *$ & $-0.599^{* * *}$ & $-0.736^{* * *}$ & 0.205 & $-0.095^{* * *}$ & -0.109 \\
& $(7.426)$ & $(1.629)$ & $(-2.848)$ & $(-4.339)$ & $(-16.207)$ & $(0.973)$ & $(-2.716)$ & $(-0.938)$ \\
Other Controls & Yes & Yes & Yes & Yes & Yes & Yes & Yes & Yes \\
\hline Number of Observations & 2,258 & 2,258 & 2,258 & 2,258 & 2,258 & 2,258 & 2,258 & 2,258 \\
Adjusted R-squared & 0.174 & 0.241 & 0.285 & 0.163 & 0.253 & 0.245 & 0.166 & 0.168 \\
\hline
\end{tabular}

\begin{tabular}{|c|c|c|c|c|c|c|c|c|}
\hline Panel B & $\begin{array}{c}\Delta \text { Capital } \\
\text { Ratio }\end{array}$ & $\begin{array}{l}\text { Capital } \\
\text { Growth }\end{array}$ & $\begin{array}{l}\text { Loan } \\
\text { Growth }\end{array}$ & $\begin{array}{c}\Delta \text { Asset } \\
\text { Risk }\end{array}$ & $\begin{array}{l}\text { Capital } \\
\text { Buffer }\end{array}$ & $\begin{array}{c}\text { Tier } 1 \\
\text { Capital } \\
\text { Growth } \\
\end{array}$ & $\Delta$ Leverage & $\Delta$ Liquid Assets \\
\hline \multicolumn{9}{|l|}{ CAPITAL REQUIREMENT } \\
\hline$\Delta$ Capital Requirement $^{+}$ & $\begin{array}{c}0.217 * * * \\
(3.451)\end{array}$ & $\begin{array}{c}0.052 \\
(0.196)\end{array}$ & $\begin{array}{c}-0.255 \\
(-1.254)\end{array}$ & $\begin{array}{c}-0.749 * * * \\
(-3.804)\end{array}$ & $\begin{array}{c}-0.826 * * * \\
(-12.778)\end{array}$ & $\begin{array}{c}-0.321 \\
(-1.070)\end{array}$ & $\begin{array}{c}0.017 \\
(0.344)\end{array}$ & $\begin{array}{c}0.000 \\
(0.001)\end{array}$ \\
\hline I $\Delta$ Capital Requirement $^{-}$I & $\begin{array}{c}-0.525 * * * \\
(-5.788)\end{array}$ & $\begin{array}{l}-0.739 * \\
(-1.954)\end{array}$ & $\begin{array}{c}0.674^{* *} \\
(2.302)\end{array}$ & $\begin{array}{c}0.336 \\
(1.185)\end{array}$ & $\begin{array}{c}0.576 * * * \\
(6.193)\end{array}$ & $\begin{array}{c}-1.131 * * * \\
(-2.624)\end{array}$ & $\begin{array}{c}0.293 * * * \\
(4.088)\end{array}$ & $\begin{array}{c}0.302 \\
(1.264)\end{array}$ \\
\hline Other Controls & Yes & Yes & Yes & Yes & Yes & Yes & Yes & Yes \\
\hline Number of Observations & 2,258 & 2,258 & 2,258 & 2,258 & 2,258 & 2,258 & 2,258 & 2,258 \\
\hline Adjusted R-squared & 0.176 & 0.241 & 0.285 & 0.164 & 0.254 & 0.247 & 0.170 & 0.168 \\
\hline
\end{tabular}




\section{Table 6}

The impact of changes in regulatory capital requirement on bank capital ratio - the loan channel The table shows OLS regression results regressing variables defined at the top of each column on control variables. $\Delta$ Capital Requirement ${ }^{+}$includes the value of a change in capital requirement when it is positive and zero otherwise. $\mid \Delta$ Capital Requirement ${ }^{-} \mid$includes the absolute value of a change in capital requirement when it is negative and zero otherwise. The control variables are the same as in the specifications in Table 3. The table uses annual averages of variables at the bank level. All variables are defined in Appendix 1. All regressions include bank and year fixed effects. The statistical significance of results is indicated by $*=10 \%$ level, $* *=5 \%$ level and $* * *=1 \%$ level using heteroscedasticity-robust standard errors. t-statistics are shown in parentheses below coefficient estimates.

\begin{tabular}{|c|c|c|c|c|c|c|}
\hline \multirow{2}{*}{ CAPITAL REQUIREMENT } & \multicolumn{2}{|c|}{ Retail Loan Growth } & \multicolumn{2}{|c|}{ Firm Loan Growth } & \multicolumn{2}{|c|}{ Public Institution Loan Growth } \\
\hline & & & & & & \\
\hline \multirow[t]{2}{*}{$\Delta$ Capital Requirement } & -3.646 & & $-6.148 * *$ & & -10.656 & \\
\hline & $(-1.350)$ & & $(-2.491)$ & & $(-1.079)$ & \\
\hline \multirow[t]{2}{*}{$\Delta$ Capital Requirement $^{+}$} & & -3.230 & & -3.626 & & -16.390 \\
\hline & & $(-0.966)$ & & $(-1.056)$ & & $(-1.348)$ \\
\hline \multirow[t]{2}{*}{$\mid \Delta$ Capital Requirement $^{-} \mid$} & & 4.763 & & $12.974 * *$ & & -11.726 \\
\hline & & $(0.637)$ & & $(2.071)$ & & $(-0.350)$ \\
\hline Other Controls & Yes & Yes & Yes & Yes & Yes & Yes \\
\hline Number of Observations & 492 & 492 & 493 & 493 & 152 & 152 \\
\hline Adjusted R-squared & 0.212 & 0.210 & 0.283 & 0.285 & -0.003 & -0.010 \\
\hline
\end{tabular}




\section{Table 7}

The exogeneity of the impact of changes in regulatory capital requirement on bank capital ratio The table shows the second step of two-step GMM regression results of a simultaneous equations estimation regressing variables defined at the top of each column on control variables. FSA on-site visit is a dummy variable in the quarter when the Danish FSA inspects a bank on-site and adjusts the bank's capital requirement. The control variables are the same as shown in Table 3. All variables are used at the bank-quarter level and defined in Appendix 1. All equations include bank and quarter fixed effects. For the two-step GMM estimator, the first step estimates each equation via 2SLS using the first lag of the dependent variables as instruments, where a Fisher type unit root test based on the Phillips-Perron test rejects a unit root and a Wooldridge test rejects autocorrelation in panel data in all cases. A weight matrix is then calculated which is used in the second step of GMM. The dependent variables are taken to be endogenous to the system and treated as correlated with the disturbances in the system's equations. The statistical significance of results is indicated by $*=10 \%$ level, $* *=5 \%$ level and $* * *=1 \%$ level using heteroscedasticity-robust standard errors. t-statistics are shown in parentheses below coefficient estimates.

\begin{tabular}{|c|c|c|c|c|c|c|c|}
\hline & $\begin{array}{c}\Delta \text { Capital } \\
\text { Ratio }\end{array}$ & $\begin{array}{l}\text { Capital } \\
\text { Growth }\end{array}$ & $\begin{array}{c}\text { Loan } \\
\text { Growth }\end{array}$ & $\begin{array}{c}\Delta \text { Asset } \\
\text { Risk }\end{array}$ & $\begin{array}{l}\text { Capital } \\
\text { Buffer }\end{array}$ & $\begin{array}{c}\text { Tier } 1 \\
\text { Capital } \\
\text { Growth }\end{array}$ & $\Delta$ Leverage \\
\hline \multicolumn{8}{|l|}{ CAPITAL REQUIREMENT } \\
\hline$\Delta$ Capital Requirement (CR) & $\begin{array}{c}0.413 * * * \\
(9.156)\end{array}$ & $\begin{array}{c}0.281 \\
(1.612)\end{array}$ & $\begin{array}{c}-0.413^{* * *} \\
(-3.007)\end{array}$ & $\begin{array}{c}-0.644 * * * \\
(-4.765)\end{array}$ & $\begin{array}{c}-0.654 * * * \\
(-13.578)\end{array}$ & $\begin{array}{c}0.200 \\
(1.006)\end{array}$ & $\begin{array}{c}-0.100 * * * \\
(-2.886)\end{array}$ \\
\hline FSA on-site visit & $\begin{array}{c}-0.334 \\
(-1.221)\end{array}$ & $\begin{array}{c}-3.177 * * * \\
(-2.995)\end{array}$ & $\begin{array}{c}-0.859 \\
(-1.029)\end{array}$ & $\begin{array}{c}1.015 \\
(1.236)\end{array}$ & $\begin{array}{c}-0.151 \\
(-0.516)\end{array}$ & $\begin{array}{c}-4.904 * * * \\
(-4.061)\end{array}$ & $\begin{array}{c}0.598 * * * \\
(2.854)\end{array}$ \\
\hline$\Delta \mathrm{CR} * \mathrm{FSA}$ on-site visit & $\begin{array}{c}-0.094 \\
(-0.523)\end{array}$ & $\begin{array}{c}0.702 \\
(1.014)\end{array}$ & $\begin{array}{c}0.329 \\
(0.603)\end{array}$ & $\begin{array}{c}-0.646 \\
(-1.205)\end{array}$ & $\begin{array}{c}-0.135 \\
(-0.707)\end{array}$ & $\begin{array}{c}1.085 \\
(1.376)\end{array}$ & $\begin{array}{c}-0.052 \\
(-0.381)\end{array}$ \\
\hline Other Controls & Yes & Yes & Yes & Yes & Yes & Yes & Yes \\
\hline Number of Observations & 2,490 & 2,490 & 2,490 & 2,490 & 2,490 & 2,490 & 2,490 \\
\hline Adjusted R-squared & 0.182 & 0.229 & 0.273 & 0.149 & 0.221 & 0.236 & 0.149 \\
\hline
\end{tabular}




\section{Table 8}

The impact of changes in regulatory capital requirement on bank capital ratio for SIFIs

The table shows the second step of two-step GMM regression results of a simultaneous equations estimation regressing variables defined at the top of each column on control variables. $\Delta$ Capital Requirement+ includes the value of a change in capital requirement when it is positive and zero otherwise. $\mid \Delta$ Capital Requirement $-I$ includes the absolute value of a change in capital requirement when it is negative and zero otherwise. SIFI is a dummy variable for systemically important financial institutions as defined by the Danish FSA. The control variables are the same as shown in Table 3. All variables are used at the bank-quarter level and defined in Appendix 1. All equations include bank and quarter fixed effects. For the two-step GMM estimator, the first step estimates each equation via 2SLS using the first lag of the dependent variables as instruments, where a Fisher type unit root test based on the Phillips-Perron test rejects a unit root and a Wooldridge test rejects autocorrelation in panel data in all cases. A weight matrix is then calculated which is used in the second step of GMM. The dependent variables are taken to be endogenous to the system and treated as correlated with the disturbances in the system's equations. The statistical significance of results is indicated by $*=10 \%$ level, $* *=5 \%$ level and $* * *=1 \%$ level using heteroscedasticityrobust standard errors. t-statistics are shown in parentheses below coefficient estimates.

\begin{tabular}{|c|c|c|c|c|c|c|c|}
\hline Panel A & $\begin{array}{c}\Delta \text { Capital } \\
\text { Ratio }\end{array}$ & $\begin{array}{l}\text { Capital } \\
\text { Growth }\end{array}$ & $\begin{array}{c}\text { Loan } \\
\text { Growth }\end{array}$ & $\begin{array}{c}\Delta \text { Asset } \\
\text { Risk }\end{array}$ & $\begin{array}{l}\text { Capital } \\
\text { Buffer }\end{array}$ & $\begin{array}{c}\text { Tier } 1 \\
\text { Capital } \\
\text { Growth }\end{array}$ & $\Delta$ Leverage \\
\hline \multicolumn{8}{|l|}{ CAPITAL REQUIREMENT } \\
\hline$\Delta$ Capital Requirement & $\begin{array}{c}0.373 * * * \\
(8.098)\end{array}$ & $\begin{array}{c}0.162 \\
(0.905)\end{array}$ & $\begin{array}{c}-0.506^{* * *} \\
(-3.606)\end{array}$ & $\begin{array}{c}-0.691 * * * \\
(-5.007)\end{array}$ & $\begin{array}{c}-0.697 * * * \\
(-14.179)\end{array}$ & $\begin{array}{c}0.059 \\
(0.288)\end{array}$ & $\begin{array}{c}-0.070 * * \\
(-1.972)\end{array}$ \\
\hline$\Delta$ Capital Requirement $*$ SIFI & $\begin{array}{c}0.165 \\
(1.252)\end{array}$ & $\begin{array}{c}0.661 \\
(1.297)\end{array}$ & $\begin{array}{l}0.761^{*} \\
(1.901)\end{array}$ & $\begin{array}{c}0.162 \\
(0.412)\end{array}$ & $\begin{array}{c}0.207 \\
(1.475)\end{array}$ & $\begin{array}{c}0.669 \\
(1.153)\end{array}$ & $\begin{array}{c}-0.124 \\
(-1.236)\end{array}$ \\
\hline Other Controls & Yes & Yes & Yes & Yes & Yes & Yes & Yes \\
\hline Number of Observations & 2,490 & 2,490 & 2,490 & 2,490 & 2,490 & 2,490 & 2,490 \\
\hline Adjusted R-squared & 0.181 & 0.227 & 0.273 & 0.149 & 0.221 & 0.231 & 0.146 \\
\hline
\end{tabular}

\begin{tabular}{|c|c|c|c|c|c|c|c|}
\hline Panel B & $\begin{array}{c}\Delta \text { Capital } \\
\text { Ratio }\end{array}$ & $\begin{array}{l}\text { Capital } \\
\text { Growth }\end{array}$ & $\begin{array}{c}\text { Loan } \\
\text { Growth }\end{array}$ & $\begin{array}{c}\Delta \text { Asset } \\
\text { Risk }\end{array}$ & $\begin{array}{l}\text { Capital } \\
\text { Buffer }\end{array}$ & $\begin{array}{c}\text { Tier } 1 \\
\text { Capital } \\
\text { Growth }\end{array}$ & $\Delta$ Leverage \\
\hline \multicolumn{8}{|l|}{ CAPITAL REQUIREMENT } \\
\hline$\Delta$ Capital Requirement $^{+}$ & $\begin{array}{c}0.239 * * * \\
(3.640)\end{array}$ & $\begin{array}{c}-0.169 \\
(-0.662)\end{array}$ & $\begin{array}{c}-0.235 \\
(-1.171)\end{array}$ & $\begin{array}{c}-0.923 * * * \\
(-4.674)\end{array}$ & $\begin{array}{c}-0.847 * * * \\
(-12.062)\end{array}$ & $\begin{array}{l}-0.551 * \\
(-1.895)\end{array}$ & $\begin{array}{c}0.072 \\
(1.429)\end{array}$ \\
\hline $\mid \Delta$ Capital Requirement $^{-} \mid$ & $\begin{array}{c}-0.607 * * * \\
(-6.425)\end{array}$ & $\begin{array}{c}-0.744 * * \\
(-2.026)\end{array}$ & $\begin{array}{c}0.983^{* * *} * \\
(3.408)\end{array}$ & $\begin{array}{c}0.284 \\
(1.000)\end{array}$ & $\begin{array}{c}0.435^{* * *} * \\
(4.302)\end{array}$ & $\begin{array}{c}-1.131 * * * \\
(-2.705)\end{array}$ & $\begin{array}{c}0.318 * * * \\
(4.400)\end{array}$ \\
\hline$\Delta$ Capital Requirement $^{+} *$ SIFI & $\begin{array}{c}-0.039 \\
(-0.199)\end{array}$ & $\begin{array}{l}1.417^{*} \\
(1.867)\end{array}$ & $\begin{array}{c}0.301 \\
(0.504)\end{array}$ & $\begin{array}{c}0.629 \\
(1.071)\end{array}$ & $\begin{array}{c}0.226 \\
(1.080)\end{array}$ & $\begin{array}{l}1.644 * \\
(1.902)\end{array}$ & $\begin{array}{c}-0.313 * * \\
(-2.093)\end{array}$ \\
\hline $\mid \Delta$ Capital Requirement $^{-} \mid *$ SIFI & $\begin{array}{l}-0.428 * \\
(-1.683)\end{array}$ & $\begin{array}{c}0.543 \\
(0.550)\end{array}$ & $\begin{array}{l}-1.512 * \\
(-1.950)\end{array}$ & $\begin{array}{c}0.588 \\
(0.769)\end{array}$ & $\begin{array}{c}-0.139 \\
(-0.511)\end{array}$ & $\begin{array}{c}0.932 \\
(0.828)\end{array}$ & $\begin{array}{c}-0.192 \\
(-0.987)\end{array}$ \\
\hline Other Controls & Yes & Yes & Yes & Yes & Yes & Yes & Yes \\
\hline Number of Observations & 2,490 & 2,490 & 2,490 & 2,490 & 2,490 & 2,490 & 2,490 \\
\hline
\end{tabular}




\section{Table 9}

The impact of changes in regulatory capital requirement on bank capital ratio in different market regimes

The table shows the second step of two-step GMM regression results of a simultaneous equations estimation regressing variables defined at the top of each column on control variables. Confidential disclosure is a dummy variable which is one in the period 2007 to 2009 when banks had to disclose their capital ratio requirement only to the supervisor. Public disclosure is a dummy variable which is one in the period 2010 until the end of our observation period when banks had to disclose their capital ratio requirement publicly. "Hard" enforcement is a dummy variable which is one from 2007 until 2012 when the supervisor closed a bank when it violated its capital ratio. "Soft" enforcement is a dummy variable which is one from 2013 until the end of our observation period the supervisor implemented supervisory actions but a bank was not closed when it breached its capital ratio. $\Delta$ Capital Requirement+ includes the value of a change in capital requirement when it is positive and zero otherwise. $\mid \Delta$ Capital Requirement - I includes the absolute value of a change in capital requirement when it is negative and zero otherwise. The control variables are the same as shown in Table 3. All variables are used at the bank-quarter level and defined in Appendix 1. All equations include bank and quarter fixed effects. For the two-step GMM estimator, the first step estimates each equation via 2SLS using the first lag of the dependent variables as instruments, where a Fisher type unit root test based on the Phillips-Perron test rejects a unit root and a Wooldridge test rejects autocorrelation in panel data in all cases. A weight matrix is then calculated which is used in the second step of GMM. The dependent variables are taken to be endogenous to the system and treated as correlated with the disturbances in the system's equations. The statistical significance of results is indicated by $*=10 \%$ level, $* *=5 \%$ level and $* * *=1 \%$ level using heteroscedasticity-robust standard errors. t-statistics are shown in parentheses below coefficient estimates.

\begin{tabular}{|c|c|c|c|c|c|c|c|}
\hline Panel A & $\begin{array}{c}\Delta \text { Capital } \\
\text { Ratio }\end{array}$ & $\begin{array}{l}\text { Capital } \\
\text { Growth }\end{array}$ & $\begin{array}{c}\text { Loan } \\
\text { Growth }\end{array}$ & $\begin{array}{c}\Delta \text { Asset } \\
\text { Risk }\end{array}$ & $\begin{array}{l}\text { Capital } \\
\text { Buffer }\end{array}$ & $\begin{array}{c}\text { Tier } 1 \\
\text { Capital } \\
\text { Growth }\end{array}$ & $\Delta$ Leverage \\
\hline \multicolumn{8}{|l|}{ CAPITAL REQUIREMENT } \\
\hline $\begin{array}{l}\Delta \text { Capital Requirement } * \\
\text { Regime } 1 \text { (conf., hard) }\end{array}$ & $\begin{array}{c}0.385 * * * \\
(5.167)\end{array}$ & $\begin{array}{c}0.452 \\
(1.563)\end{array}$ & $\begin{array}{c}0.030 \\
(0.134)\end{array}$ & $\begin{array}{c}-0.760 * * * \\
(-3.395)\end{array}$ & $\begin{array}{c}-0.737 * * * \\
(-9.245)\end{array}$ & $\begin{array}{l}0.571 * \\
(1.731)\end{array}$ & $\begin{array}{c}-0.174 * * * \\
(-3.041)\end{array}$ \\
\hline$\Delta$ Capital Requirement $*$ & $0.489 * * *$ & 0.354 & $-0.713 * * *$ & $-0.745 * * *$ & $-0.544 * * *$ & 0.242 & $-0.096^{* *}$ \\
\hline Regime 2 (public, hard) & (7.806) & $(1.454)$ & $(-3.732)$ & $(-3.956)$ & $(-8.126)$ & $(0.872)$ & $(-2.007)$ \\
\hline$\Delta$ Capital Requirement $*$ & $0.185^{*}$ & -0.349 & -0.433 & -0.356 & $-0.858 * * *$ & $-0.786^{*}$ & 0.086 \\
\hline Regime 3 (public, soft) & $(1.931)$ & $(-0.939)$ & $(-1.483)$ & $(-1.239)$ & $(-8.391)$ & $(-1.857)$ & $(1.166)$ \\
\hline Other Controls & Yes & Yes & Yes & Yes & Yes & Yes & Yes \\
\hline Number of Observations & 2,490 & 2,490 & 2,490 & 2,490 & 2,490 & 2,490 & 2,490 \\
\hline Adjusted R-squared & 0.183 & 0.227 & 0.274 & 0.149 & 0.222 & 0.232 & 0.148 \\
\hline
\end{tabular}


Table 9 cont.

The impact of changes in regulatory capital requirement on bank capital ratio in different market regimes

\begin{tabular}{|c|c|c|c|c|c|c|c|}
\hline Panel B & $\begin{array}{l}\Delta \text { Capital } \\
\text { Ratio }\end{array}$ & $\begin{array}{l}\text { Capital } \\
\text { Growth }\end{array}$ & $\begin{array}{l}\text { Loan } \\
\text { Growth }\end{array}$ & $\begin{array}{l}\Delta \text { Asset } \\
\text { Risk }\end{array}$ & $\begin{array}{l}\text { Capital } \\
\text { Buffer }\end{array}$ & $\begin{array}{c}\text { Tier } 1 \\
\text { Capital } \\
\text { Growth }\end{array}$ & $\Delta$ Leverage \\
\hline \multicolumn{8}{|c|}{ CAPITAL REQUIREMENT - DIRECTION AND REGIME } \\
\hline $\begin{array}{l}\Delta \text { Capital Requirement }^{+} * \text { Regime } 1 \\
\text { (Confidential Disclosure, "Hard" Enforcement) }\end{array}$ & $\begin{array}{c}0.256 * * * \\
(2.599)\end{array}$ & $\begin{array}{c}0.167 \\
(0.436)\end{array}$ & $\begin{array}{c}0.128 \\
(0.426)\end{array}$ & $\begin{array}{c}-0.993 * * * \\
(-3.347)\end{array}$ & $\begin{array}{c}-0.870^{* * *} \\
(-8.257)\end{array}$ & $\begin{array}{c}0.149 \\
(0.342)\end{array}$ & $\begin{array}{l}-0.082 \\
(-1.085)\end{array}$ \\
\hline $\begin{array}{l}\Delta \text { Capital Requirement }{ }^{+} * \text { Regime } 2 \\
\text { (Public Disclosure, "Hard" Enforcement) }\end{array}$ & $\begin{array}{c}0.271 * * * \\
(2.926)\end{array}$ & $\begin{array}{c}0.074 \\
(0.206)\end{array}$ & $\begin{array}{l}-0.159 \\
(-0.564)\end{array}$ & $\begin{array}{l}-0.950 * * * \\
(-3.416)\end{array}$ & $\begin{array}{l}-0.750 * * * \\
(-7.583)\end{array}$ & $\begin{array}{c}-0.403 \\
(-0.984)\end{array}$ & $\begin{array}{c}0.065 \\
(0.921)\end{array}$ \\
\hline $\begin{array}{l}\Delta \text { Capital Requirement }{ }^{+} * \text { Regime } 3 \\
\text { (Public Disclosure, "Soft" Enforcement) }\end{array}$ & $\begin{array}{c}0.111 \\
(0.825)\end{array}$ & $\begin{array}{c}-0.458 \\
(-0.879)\end{array}$ & $\begin{array}{l}-0.797 * \\
(-1.948)\end{array}$ & $\begin{array}{l}-0.376 \\
(-0.931)\end{array}$ & $\begin{array}{c}-0.896 * * * \\
(-6.254)\end{array}$ & $\begin{array}{r}-1.177 * * \\
(-1.984)\end{array}$ & $\begin{array}{l}0.186^{*} \\
(1.811)\end{array}$ \\
\hline $\begin{array}{l}\mid \Delta \text { Capital Requirement }^{-} \mid * \text { Regime } 1 \\
\text { (Confidential Disclosure, "Hard" Enforcement) }\end{array}$ & $\begin{array}{l}-0.621 * * * \\
(-4.225)\end{array}$ & $\begin{array}{l}-0.989 * \\
(-1.731)\end{array}$ & $\begin{array}{c}0.113 \\
(0.251)\end{array}$ & $\begin{array}{c}0.321 \\
(0.726)\end{array}$ & $\begin{array}{c}0.491 * * * \\
(3.129)\end{array}$ & $\begin{array}{l}-1.345^{* *} \\
(-2.069)\end{array}$ & $\begin{array}{l}0.341^{* * * *} \\
(3.028)\end{array}$ \\
\hline $\begin{array}{l}\mid \Delta \text { Capital Requirement }^{-} \mid * \text { Regime } 2 \\
\text { (Public Disclosure, "Hard" Enforcement) }\end{array}$ & $\begin{array}{l}-0.837 * * * \\
(-6.735)\end{array}$ & $\begin{array}{l}-0.800 * \\
(-1.655)\end{array}$ & $\begin{array}{c}1.588 * * * \\
(4.192)\end{array}$ & $\begin{array}{c}0.417 \\
(1.114)\end{array}$ & $\begin{array}{l}0.219^{*} \\
(1.649)\end{array}$ & $\begin{array}{l}-1.264 * * \\
(-2.299)\end{array}$ & $\begin{array}{c}0.353 * * * \\
(3.705)\end{array}$ \\
\hline $\begin{array}{l}\mid \Delta \text { Capital Requirement }{ }^{-} \mid * \text { Regime } 3 \\
\text { (Public Disclosure, "Soft" Enforcement) }\end{array}$ & $\begin{array}{l}-0.317 \\
(-1.637)\end{array}$ & $\begin{array}{c}0.153 \\
(0.203)\end{array}$ & $\begin{array}{l}-0.223 \\
(-0.378)\end{array}$ & $\begin{array}{c}0.321 \\
(0.551)\end{array}$ & $\begin{array}{c}0.791 * * * \\
(3.827)\end{array}$ & $\begin{array}{c}0.089 \\
(0.104)\end{array}$ & $\begin{array}{c}0.093 \\
(0.630)\end{array}$ \\
\hline Other Controls & Yes & Yes & Yes & Yes & Yes & Yes & Yes \\
\hline Number of Observations & 2,490 & 2,490 & 2,490 & 2,490 & 2,490 & 2,490 & 2,490 \\
\hline Adjusted R-squared & 0.188 & 0.228 & 0.277 & 0.150 & 0.226 & 0.234 & 0.153 \\
\hline
\end{tabular}




\section{Appendix A1. Description of Variables}

The table shows descriptions of virtually all variables used in the analyses.

\begin{tabular}{|c|c|}
\hline Variable & Description \\
\hline$\Delta$ Capital Ratio & $\begin{array}{l}\text { The quarterly percentage point change of the ratio of Tier } 1 \text { and Tier } 2 \text { capital divided by risk- } \\
\text { weighted assets. }\end{array}$ \\
\hline Capital growth & $\begin{array}{l}\text { The logarithmic equity capital growth calculated as the logarithm of the ratio of the sum of Tier } 1 \\
\text { and Tier } 2 \text { capital in the current quarter divided by its value in the previous quarter, times } 100 \text {. }\end{array}$ \\
\hline Tier 1 capital growth & $\begin{array}{l}\text { The logarithmic Tier } 1 \text { capital growth calculated as the logarithm of the ratio of Tier } 1 \text { capital in } \\
\text { the current quarter divided by its value in the previous quarter, times } 100 \text {. }\end{array}$ \\
\hline$\Delta$ Leverage & $\begin{array}{l}\text { The quarterly difference of the ratio of a bank's assets plus loan commitments divided by Tier } 1 \\
\text { capital. }\end{array}$ \\
\hline Loan Growth & $\begin{array}{l}\text { The logarithmic loan growth calculated as the logarithm of the ratio of the sum of loans and loan } \\
\text { commitments in the current quarter divided by its value in the previous quarter, times } 100 \text {. }\end{array}$ \\
\hline Loan Ratio & The ratio of loans and loan commitments to total assets and loan commitments. \\
\hline$\Delta$ Asset Risk & The quarterly percentage point change of risk-weighted assets divided by total assets. \\
\hline Capital buffer & The difference between the actual capital ratio and the regulatory minimum ratio. \\
\hline \multicolumn{2}{|c|}{ FURTHER BANK-SPECIFIC VARIABLES } \\
\hline Assets & Total assets as recorded in the balance sheet. \\
\hline STD RoA & $\begin{array}{l}\text { The annualized standard deviation of a bank's return on assets calculated over the previous } 16 \\
\text { quarters. }\end{array}$ \\
\hline Loan loss reserves & Loan loss provision in percent of the gross lending exposure. \\
\hline Charge offs & Quarterly loan charge offs in percent of the gross lending exposure. \\
\hline Net interest income & The difference between interest earnings and expenditures divided by total assets. \\
\hline Liquid Assets & The ratio of liquid assets to total assets. \\
\hline M\&A & $\begin{array}{l}\text { Dummy variable which is one in the quarter when a bank is involved itself in a completed bank } \\
\text { M\&A. }\end{array}$ \\
\hline IRB & $\begin{array}{l}\text { Dummy variable which is one in the quarter when a bank switches to the internal ratings-based } \\
\text { approach. }\end{array}$ \\
\hline Mortgage Bank & Dummy variable which is one when the bank is a mortgage bank. \\
\hline Savings Bank & Dummy variable which is one when the bank is a savings bank. \\
\hline
\end{tabular}

